\title{
The conservation value of germplasm stored at the Millennium Seed Bank, Royal Botanic Gardens, Kew, UK
}

\author{
Udayangani Liu ${ }^{1}$ (D) $\cdot$ Elinor Breman ${ }^{1} \cdot$ Tiziana Antonella Cossu $^{1} \cdot$ Siobhan Kenney $^{1,2}$
}

Received: 29 August 2017 / Revised: 17 November 2017 / Accepted: 2 January 2018 /

Published online: 13 January 2018

(C) The Author(s) 2018. This article is an open access publication

\begin{abstract}
The Millennium Seed Bank (MSB) Partnership, developed and managed by the Royal Botanic Gardens, Kew (RBG Kew), conserves propagules primarily from orthodox seed-bearing wild vascular plants. It is the largest ex situ conservation programme in the world, currently involving 96 countries and territories. Where possible, seeds are collected and conserved in the country of origin with duplicates being sent to RBG Kew's MSB for storage. In this paper we assess the conservation value of the germplasm stored at the MSB using both quantitative and qualitative methods. The MSB holdings represent a high quality, rich biological resource. Substantial and unique taxonomic diversity exists amongst the collections, representing 365 families, 5813 genera, 36,975 species and 39,669 taxa conserved. The collections cover a wide geographic range, originating from 189 countries and territories, representing all nine bio-geographic regions and all 35 biodiversity hotspots. The collections possess significant natural capital and population value: $32 \%$ of taxa, representing $49 \%$ of collections, have at least one identified use to humans; and $74 \%$ of taxa, representing $78 \%$ of collections, are either endemic, endangered (nationally or globally) and/or have an economic, ecological, social, cultural or scientific value. While $10 \%$ of taxa, representing $>8 \%$ of collections, are either extinct, rare or vulnerable to extinction at the global and/or national level, $20 \%$ of taxa, representing $13 \%$ collections, are endemic at the country or territory scale. Over the 17 -year period since 2000 at least 11,182 seed
\end{abstract}

Communicated by Daniel Sanchez Mata.

This article belongs to the Topical Collection: Ex-situ conservation.

Electronic supplementary material The online version of this article (https://doi.org/10.1007/s105 31-018-1497-y) contains supplementary material, which is available to authorized users.

Udayangani Liu

u.liu@kew.org

1 Royal Botanic Gardens, Kew, Wellcome Trust Millennium Building, Wakehurst, Ardingly, West Sussex RH17 6TN, England, UK

2 Present Address: Conservation Programmes, Zoological Society of London, Regents Park, London NW1 4RY, England, UK 
samples, representing $12 \%$ of taxa and $8 \%$ of collections, have been distributed globally for conservation, research, education and display. This analysis highlighted collection gaps in MSB holdings in relation to their geographic representativeness, the taxonomic diversity of large families and genera of angiosperms, and coverage of threatened taxa. Further analysis across the entire MSB Partnership is required to underpin future collection activities and maximize the usefulness of collections.

Keywords Ex situ conservation · Seed banking · Vulnerability to extinction · Rarity · Uniqueness · Irreplaceability $\cdot$ Natural capital value $\cdot$ GSPC

\section{Introduction}

The long-term storage of germplasm in the form of seeds is central to an integrated in situ and ex situ conservation strategy, and together with botanic gardens is one of the most widespread and valuable approaches to ex situ plant conservation. Crop germplasm has been conserved in seed banks for over 60 years and the Royal Botanic Gardens, Kew (RBG Kew) has followed this work since the late 1960s, adapting the techniques for the conservation of 'wild' species. The Millennium Seed Bank (MSB) Project established in 1995 is a plant conservation partnership between RBG Kew and organizations both within the UK and across the globe. It is the largest ex situ plant seed conservation program for wild species in the world (Smith et al. 1998). Seed banking remains a key part of RBG Kew's Science Strategy (RBG Kew 2015), while also contributing to Target 8 (at least $75 \%$ of threatened plant species conserved in ex situ collections, preferably in the country of origin, and at least $20 \%$ available for recovery and restoration programs) and Target 9 (70\% of the genetic diversity of crops including their wild relatives and other socio-economically valuable plant species conserved, while respecting, preserving and maintaining associated indigenous and local knowledge) of the Global Strategy for Plant Conservation (CBD 2012).

The MSB Project's International Program successfully conserved 10\% of the world's wild orthodox seed-bearing flora between 2000 and 2010. The MSB Partnership (MSBP, 2011 to present) currently involves 96 countries and territories, with active projects in 54 countries. The main aim of MSBP is to continue safeguarding plant diversity worldwide with a focus on plants most at risk and most useful for the future, while addressing global challenges for food security, sustainable energy, loss of biodiversity and climate change. With one in five vascular plant species currently threatened with extinction (RBG Kew 2016), the need for such conservation measures has never been greater.

Traditional seed banking focuses on the storage of orthodox seeds, those that can be dried (to $15 \%$ equilibrium relative humidity) and stored at low temperatures $\left(-20{ }^{\circ} \mathrm{C}\right)$, in air-tight containers to maximise their longevity. For every $10 \%$ decrease in equilibrium relative humidity and $5{ }^{\circ} \mathrm{C}$ drop in temperature the lifespan of orthodox seeds is doubled (Harrington 1960). Thus, under conventional storage conditions seeds can be expected to live for 10-100 s, if not $1000 \mathrm{~s}$, of years, the longevity being dependent on the species and seed traits. The ability to store a large diversity of germplasm in a small space at relatively low cost makes seed banking a practical and attractive tool for plant conservation.

There are more than 1750 seed banks in the world, the majority of which conserve crop diversity (Hay and Probert 2013). Since the Global Strategy for Plant Conservation (GSPC) was adopted by the Convention on Biological Diversity (CBD) in 2002, the number of 
ex situ conservation facilities for wild species has grown dramatically, but little information is available about the extent to which plant species are appropriately represented in ex situ collections (Godefroid et al. 2011; Cibrian-Jaramillo et al. 2013; Rivière and Müller 2017; Teixido et al. 2017). This study assesses the conservation value, both qualitative and quantitative, of germplasm conserved in MSB in terms of its: (1) biological status; (2) taxonomic diversity (Ojeda et al. 1996); (3) geographic representativeness (Godefroid et al. 2011; Cibrian-Jaramillo et al. 2013; Kricsfalusy and Trevisan 2014); (4) vulnerability to extinction (Rivière and Müller 2017); (5) uniqueness and irreplaceability (Vane-Wright et al. 1991; Ojeda et al. 1995; Isaac et al. 2007); (6) natural capital value; (7) population value; (8) germplasm quality; and (9) use for conservation, research, education and display. Our analysis excludes germplasm conserved under the MSBP in the country of origin and not duplicated in MSB.

\section{Materials and methods}

Data for collections were extracted from the MSB Seed Bank Database (SBD) on 31 March 2017. SBD contains in-depth information on seed collections including their heredity, taxonomic identification, geographic origin (bio-geographic region, country, major and minor administrative divisions, locality, geographic coordinates and altitude), habitat (type, associated species, threats, land use, geology, slope, aspect and soil texture), sampled population (abundance, vulnerability, number of plants found, and sampled and area sampled), ethnobotanical uses, quantity, viability, germination, regeneration, propagation and use of collections for conservation, research, education and display.

\section{Biological status}

In determining the biological status of a collection (wild or cultivated origin), heredity, geographic origin, habitat, taxonomy and regeneration data were used. Collections originating from natural or semi-natural habitats were considered as 'wild' and those originating from cultivated habitats (e.g. orchards, home gardens and botanic gardens) and propagation or regeneration activities were considered as 'cultivated' (Alercia et al. 2012).

\section{Taxonomic diversity}

Species and taxon abundance and taxonomic composition in terms of families and genera were estimated using the current plant identification status of collections. The representativeness of angiosperm (flowering plant) families was estimated as the percentage of genera and species conserved at the MSB within the family against the total number of naturally occurring genera and species described for the family. Likewise, the representativeness of angiosperm genera was estimated as the percentage of species conserved in the MSB within each genus against the total number of naturally occurring species described for each genus. The total number of accepted genera and species described per family and accepted species described per genus were taken from The Plant List (2013) considering the confidence level and review status of names. If data was not available in The Plant List (2013), or the taxonomy of SBD data was in doubt, problematic taxa were excluded from the analysis. Therefore, angiosperm analysis was restricted to 324 families and 5341 genera. 


\section{Geographic representativeness}

Geographic origin data were used to yield digital maps and total numbers of taxa and collections originating from bio-geographic regions and countries using ArcInfo and ArcView software. If coordinates were wrong or missing, new coordinates were assigned based on the locality description for the collection where possible. Cultivated collections inherited the geographic origin of the wild plant population from which they were propagated or regenerated. Geographic data were analysed to describe geographic coverage and gaps in geographic representation including representation of MSB collections from the 35 Biodiversity Hotspots described by Conservation International (Mittermeier et al. 2011, http:// www.conservation.org).

\section{Vulnerability to extinction}

In order to verify whether MSB taxa are extinct, rare or vulnerable to extinction in the wild, SBD taxonomic identifications were cross checked with (1) IUCN (2016) for the global scale; and (2) the National Red List (2016) for the national scale. In addition, Walter and Gillett (1998) was used to identify globally rare taxa and IUCN (2016) was used to identify taxa evaluated with lower risk of extinction at global scale.

The representativeness of taxa that are extinct, rare or vulnerable to extinction at global and national scales was assessed using IUCN Red List categories: extinct (EX); regionally extinct (RE); extinct/endangered (EX/EN); extinct/vulnerable (EX/VU); extinct in the wild (EW); critically endangered (CR); endangered (EN); endangered/vulnerable (EN/VU); vulnerable (VU); rare (R or RR); intermediate (I) and relict. The National Red List (2016) uses both IUCN and non-IUCN criteria (e.g. threatened, critical or declining) for categorizing threatened taxa. In our analysis, all non-IUCN categories from the National Red List (2016) were treated separately and presented as 'Other Threatened' taxa. Taxa categorized under lower risk of extinction in IUCN (2016) include a number of subdivisions, namely: near threatened (NT); lower risk/near threatened (LR/nt); lower risk/conservation dependent (LR/cd); lower risk/least concern (LR/lc); and least concern (LC).

For vascular plants, IUCN (2016) lists global assessments for 23,392 taxa, 12,564 (54\%) of which are listed as either extinct or vulnerable to extinction, $9028(38 \%)$ with lower risk of extinction and $1800(8 \%)$ with insufficient information for assessment. The National Red List (2016) lists 24,969 taxa as either extinct, rare or vulnerable to extinction in at least one country. Walter and Gillett (1998) list 14,998 vascular plant taxa as globally rare. To be considered as representative of nationally rare or threatened taxa, MSB collections need to originate from the country where the taxon is declared as rare, extinct or vulnerable to extinction.

\section{Uniqueness and irreplaceability}

The rarity of a taxon has been described using its geographic distribution (restricted-range endemics) and/or evolutionary distinctiveness (taxonomically distinct) (Ojeda et al. 1995; Isaac et al. 2007; Cibrian-Jaramillo et al. 2013; Kricsfalusy and Trevisan 2014). Rare taxa will have a greater risk of extinction than common ones (Johnson 1998; Matthies et al. 2004) and are considered as unique and irreplaceable in terms of their restricted distribution pattern and/or taxonomic distinctiveness. 
The most commonly used measure of uniqueness and irreplaceability in conservation is plant endemism (Stattersfield et al. 1998). Geographic distribution of plant endemism is highly taxon-dependent (Swenson et al. 2012) and describes the ecological state of a taxon being unique to a defined geographic location, such as an island, nation, country or other defined zone, or habitat type. Organisms that are indigenous to a place are not endemic to it if they are also found elsewhere.

It has been argued that maximizing evolutionary distinctiveness and phylogenetic diversity should be key components of conservation effort as the extinction of a species in an old, monotypic or species-poor clade would result in a greater loss of biodiversity than that of a young species with many close relatives (Mace et al. 2003). Building the phylogenetic diversity of ex situ collections will strengthen their capacity for use in response to biodiversity loss (Griffiths et al. 2015). Therefore, we included both rarity criteria in the analysis.

We applied the concept of endemism at the country or territory scale to identify geographic rarity. A list of endemic or near endemic taxa was compiled using a variety of reference lists including IUCN $(2015,2016)$, Walter and Gillett (1998), National Red List (2016), WCSP (2015) and SBD. As compiling a full list of endemic taxa is not practically feasible, we have utilised taxon distribution data from the MSB Species Prioritisation Tool (unpublished, Liu and Kenney) to identify endemic taxa, but we treated these designations with a low degree of confidence.

Indices of taxonomic diversity (Vane-Wright et al. 1991) are based on phylogenetic trees and provide a means of identifying distinct species (Ojeda et al. 1995). Phylogenetic studies demonstrate that evolutionary distinctiveness (ED) is derived from a few branches near the tips (i.e. those shared with few other species) and that no ED is gained in clades above $\sim 180$ species (Isaac et al. 2007). Taxonomic diversity was estimated by evaluation of the singularity of species making up communities. The taxonomic singularity of each species is directly related to the number of co-generic species in a given geographic range (Ojeda et al. 1995, 1996) and the inverse of the average number of species per genus in the community has been proposed as a simple index for assessing taxonomic distinctiveness at the community level, and quantifying its conservation value.

Ideally, the index for taxonomic singularity for the MSB taxa should be calculated from the number of species conserved for a given genus as an average of number of species normally found in a given geographic area from where the seed collections were sampled. For the purpose of this study, we used a rapid assessment method to identify the representation of less diversified and evolutionary distinct genera and families in MSB holdings (Ojeda et al. 1995). The number of genera per family and the number of species per genus were obtained from The Plant List (2013), considering the confidence level and review status of names, for angiosperm families to identify less diversified families (with up to 10 genera) and genera (with up to 10 species) and then their representation at the MSB was measured and expressed as taxonomic singularity to identify taxonomic rarity. Phylogenetic diversity of the MSB legume collections has been assessed in a separate study (Griffiths et al. 2015).

\section{Natural capital value}

Any taxon that has an identified use to humans (economic, ecological, social, cultural or scientific) was considered as a taxon with a natural capital value. We compiled 31,413 taxa with an identified use to humans from five reference sources and then used this list as a reference to verify the natural capital value of MSB taxa: (1) RBG Kew's SEPASAL-Survey of Economic Plants for Arid and Semi-Arid Lands Database (RBG Kew 1999); (2) RBG Kew's Economy Botany Collection Database (http://apps.kew.org/ecbot/search); (3) RBG 
Kew's Medicinal Plants Names Service Portal (https://www.kew.org/science/data-andresources/tools-and-services/medicinal-plant-names-services); (4) Germplasm Resources Information Network (https://www.ars-grin.gov/npgs/aboutgrin.html); and (5) Harlan and de Wet Crop Wild Relative Inventory (http://www.cwrdiversity.org/checklist/). In addition, the ethnobotanical uses listed by collectors for MSB collections were extracted from SBD and used as a further resource. As these were not supplemented with a reference, a low degree of confidence was assigned.

Crop wild relatives (CWR) are wild plant species that share a common ancestor with cultivated crop plants of socio-economic value, such as human food, animal forage and fodder crops, etc. (Fielder et al. 2015). A broad definition of a CWR is any taxon belonging to the same genus as a crop (Maxted and Kell 2009). A narrower definition of a CWR was described as "a wild plant taxon that has an indirect use derived from its relatively close genetic relationship to a crop" (Maxted et al. 2006). Three concepts are used to identify how close the relationship to a crop is: (1) Harlan and de Wet (1971) describe the genetic relationship of cultivated plants using the Gene Pool concept at three levels, this is the most commonly used concept, it is relatively objective and widely accepted (Vincent et al. 2013); (2) for the majority of crops the genetic relationship among species remains unknown, and in these cases the Taxon Group concept is used that assumes taxonomic classification is strongly linked to genetic relatedness (Maxted et al. 2006); (3) the provisional gene pool is used where there is no known gene pool concept and taxonomic treatments lack sub-generic information, but there is evidence that the crop and related taxa can be crossed (Vincent et al. 2013).

Based on different definitions, we analysed CWR taxa at two levels: (1) broad definition of CWR (sensu lato) based on any taxa in the same genus as the crop, this was verified against the consolidated list of 99 crop genera cited in Maxted et al. (2013) by combining 51 food crop genera and 81 forage crop species published by the International Treaty on Plant Genetic Resources for Food and Agriculture (FAO 2001) and 77 crop genera listed in Groombridge and Jenkins (2002); and (2) narrow definition of CWR (sensu stricto) based on any taxa specifically listed as CWR using the gene pool, taxon group and provisional gene pool concepts and was verified against 4229 taxa compiled from the Harlan and de Wet Crop Wild Relative Inventory and Germplasm Resources Information Network.

\section{Population value}

We considered taxa that are identified as endangered globally and/or nationally, endemic or near endemic at country or territory level or with a natural capital value as '3E taxa' (either endemic, endangered or economically important). Taxa that contribute to all three components were considered as significant taxa or sensu stricto $3 \mathrm{E}$ taxa with a high population value. Taxa that contribute to any component were considered as sensu lato $3 \mathrm{E}$ taxa. We use $3 \mathrm{E}$ taxon status to evaluate the population value of MSB holdings.

\section{Germplasm quality}

To be a valuable long-term resource, a collection of germplasm needs to: have accurate plant identification; be genetically representative of the species, population and individual sampled; have high viability with acceptable longevity; contain sufficient germplasm to supply intended uses; and be acquired with all consents and data to facilitate intended users (Way 2003). The key principles at the core of gene bank operations are the preservation 
of germplasm identity, maintenance of viability and genetic integrity, and the promotion of access (FAO 2014). In our study, the germplasm quality was analysed in terms of: (1) availability of key data in SBD for taxonomy (plant name), geography (bio-geographic region, country, geo-coordinates and altitude), habitat and population (number of plants found, and sampled and area sampled); (2) current status of plant identification (verified or unverified); and (3) seed quality, quantity and viability.

A sample of seeds (usually 10-50) from most MSB collections are either x-rayed or cuttested to estimate the number of full, empty and infested seeds. These data are then used as a rapid assessment method to estimate the current number of potentially viable seeds in the whole collection. The true viability of collections (germination and viability percentage) is estimated from routine germination tests throughout the life cycle of the collections. In our study, to identify seed quality, quantity and viability, collections were categorized according to their current number of potentially viable seeds (estimated using seed weights and $\mathrm{x}$-ray or cut-test results of dry seeds) and germination (germinated seeds out of seeds sown, discounting empty and infested seeds) and viability (germinated seeds plus non-germinated seeds that appeared fresh and full when cut-tested) percentage results for the most recent round of germination tests carried out at the MSB.

\section{Use of collections}

RBG Kew makes use of the seed collections stored at the MSB in research that both furthers our understanding of seed banking, and also seed biology and species conservation. Subject to terms and conditions, MSB collections with sufficient seed quantity are available to bona fide individuals from recognized organisations around the world for use in non-commercial activities in conservation, research, education and display. These collections are publicised through RBG Kew's MSB Seed List (http://apps.kew.org/seedlist/) and the Genesys website (https://www.genesys-pgr.org/wiews/GBR004), from which a small sample of germplasm can be requested by a third party. In addition, a range of seed biological trait data (storage behaviour, germination, weights, oil and protein content, dispersal and morphology) derived from MSB collections are published in RBG Kew's Seed Information Database (RBG Kew 2017, http://data.kew.org/sid/) and Try Plant Trait Database (Kattge et al. 2011, https://www.try-db.org/TryWeb/Home.php) for use in research and conservation. Although the use of physical collections and associated data are not fully documented, we used seed distribution data from January 2000 to March 2017 to assess the use of collections under four broad categories: conservation, research, education and display. Compiling a full list of scientific outputs and publications generated from MSB collections and associated data is beyond the scope of our study.

\section{Data analysis}

In order to maintain taxonomic consistency, plant Latin names and their taxonomic status (e.g. accepted, synonym, unassessed, unresolved or illegitimate) were carefully addressed in the analysis by checking plant names with the WCSP (2015), The Plant List (2013), and The International Plant Name Index (2015). If the data were not available in these resources other online sources, such as Taxonomic Name Resolution Service (http://tnrs .iplantcollaborative.org) and Tropicos.org (http://www.tropicos.org), were used.

There is variability in the precision and accuracy of data both in SBD and reference data sources mainly due to variation in the use of plant names and their taxonomic status. 
To address these concerns, prior to the main analysis, we employed an evidence-based approach matching MSB plant names with IUCN (2015) to investigate the accuracy level of estimates. Based on the results (not shown), to reduce under- or over-estimating the number of plant taxa conserved in the MSB under the different criteria applied in the analysis, the following calculation strategy was employed. When matching SBD plant names with reference data sources:

(a) The minimum value is used to describe the number of SBD taxa that match directly with reference lists. These values are reported with a high degree of confidence but are treated as an underestimate of overall representativeness.

(b) The maximum value is used to describe the number of taxa that match directly or indirectly with reference lists based on any taxonomic link. These values are reported with a low degree of confidence and are treated as an overestimate of representativeness. There are multiple examples of this: (i) SBD plant name with 'accepted' taxonomic status matches to a 'synonym' on an external list; (ii) SBD plant name with 'accepted' taxonomic status, but a synonym of it matches to a plant name which is 'accepted' on an external list; (iii) SBD plant name with 'accepted' taxonomic status and a synonym of it matches to a synonym on an external list; and (iv) SBD plant name with 'synonym' taxonomic status and the 'accepted' name of it matches to an 'accepted' name on an external list. If a synonym's accepted plant name has already been matched to an accepted plant name then it is not included again to avoid double counting.

(c) The median is the middle value between the minimum and maximum values, and is used as the total figure reported and for calculating percentages. This ensures neither under- nor over- reporting.

\section{Results}

\section{Biological status}

Of the 82,556 collections conserved in MSB, 75,749 (91.8\%) originated from material collected in natural or semi-natural habitats (wild collections) and 6807 (8.2\%) originated from either cultivated habitats or propagation and regeneration activities in the UK or elsewhere (cultivated collections).

\section{Taxonomic diversity}

The majority of the collections (99.9\%) conserved are seeds and only $0.1 \%$ are either spores or dormant organs (e.g. bulbils). MSB collections represent 365 families, 5813 genera, 36,975 species and 39,669 taxa (Table 1). Species of angiosperms contained within the Plant List (2013) belong to 405 families and 14,559 genera. About $82 \%$ of these families and $39 \%$ of these genera are represented in MSB holdings. Fifty percent of MSB collections originated from 355 families, 5558 genera, 30,956 species and 32,747 taxa, whilst the other 50\% originated from 10 families, 255 genera, 6019 species and 6922 taxa (Appendix 1; Table 2). Fifty percent of species originated from 5476 genera, whilst the other $50 \%$ of species originated from 337 genera (Supplement 1). All the naturally occurring angiosperm genera are conserved for at least 93 families, and all the naturally occurring 
Table 1 Overview of taxonomic diversity of MSB collections in terms of number of families, genera, species and taxa conserved under different vascular plant groups

\begin{tabular}{lccccc}
\hline Vascular plants & Collections & Families & Genera & Species & Taxa $^{\mathrm{a}}$ \\
\hline Angiosperms-dicots & 65,101 & 267 & 4598 & 29,420 & 31,678 \\
Angiosperms-monocots & 16,277 & 64 & 1125 & 7212 & 7609 \\
Gymnosperms & 963 & 10 & 52 & 272 & 308 \\
Lycophytes & 15 & 3 & 6 & 10 & 11 \\
Pteridophytes & 93 & 20 & 32 & 61 & 63 \\
Unknown & 107 & 1 & & & \\
Total & 82,556 & 365 & 5813 & 36,975 & 39,669 \\
\hline
\end{tabular}

Both wild and cultivated collections are considered

${ }^{a}$ Includes species, subspecies, varieties, etc.

angiosperm species conserved for at least 20 families (Appendix 1) and 949 genera (Supplement 1). For angiosperm families with one to 50 naturally occurring genera or species, more than $50 \%$ of genera are conserved for at least 150 families out of 265 and more than $50 \%$ of species conserved for at least 28 families out of 121 (Appendix 1; Table 3). Of the 12 families with many naturally occurring genera $(>200)$, three of them (Malvaceae, Leguminosae and Lamiaceae) each have more than $50 \%$ of genera conserved, and of the five families with a large number of naturally occurring species $(>10,000)$, three of them (Leguminosae, Poaceae and Compositae/Asteraceae) each have more than $10 \%$ of species conserved (Table 3; Appendix 1).

Out of the 5341 angiosperm genera analysed (Supplement 1), only 536 genera have more than 100 naturally occurring species, and these are underrepresented in MSB collections, except for nine genera which have at least $50 \%$ of their naturally occurring species conserved: Acacia (51\%, 717 out of 1393); Eucalyptus (88\%, 722 out of 822); Melaleuca (80\%, 212 out of 265); Plantago (56\%, 89 out of 158); Lachenalia (51\%, 59 out of 115); Terminalia (55\%, 60 out of 109); Gastrolobium (51\%, 54 out of 105); Pultenaea (62\%, 64 out of 104); and Protea (58\%, 59 out of 101).

\section{Geographic representativeness}

Collections originating from all nine bio-geographic regions and 189 countries and territories are stored at the MSB (Table 4). The greatest number of collections and taxa originated from Africa and the lowest numbers from the Pacific bio-geographic region. The highest number of collections were collected in Australia (11,563), UK (6779), South Africa (5858), USA (4682), Madagascar (3692), Mexico (3332), Israel (3094), Italy (3021), China (2355) and Kenya (2225) (Fig. 1). Gaps in the geographic representation of collections were Belarus, Benin, Republic of Congo, Djibouti, Equatorial Guinea, Eritrea, Iceland, Kosovo, Latvia, Moldova, Mongolia, North Korea, Paraguay, Timor-Leste, Togo, Pacific Islands (American Samoa, Cook Islands, Guam, Kiribati, Marshall Islands, Micronesia, Nauru, Niue, Northern Mariana Islands, Palau, Samoa, Tokelau, Tuvalu), Middle Eastern States (Bahrain, Kuwait, Qatar) and Caribbean Islands (Antigua and Barbuda, Barbados, Saint Kitts and Nevis, Saint Vincent and the Grenadines).

MSB collections originating from the 35 biodiversity hotspots (Mittermeier et al. 2011) are provided in Appendix 2 and illustrated in Fig. 2. They represent 53\% of MSB collections 


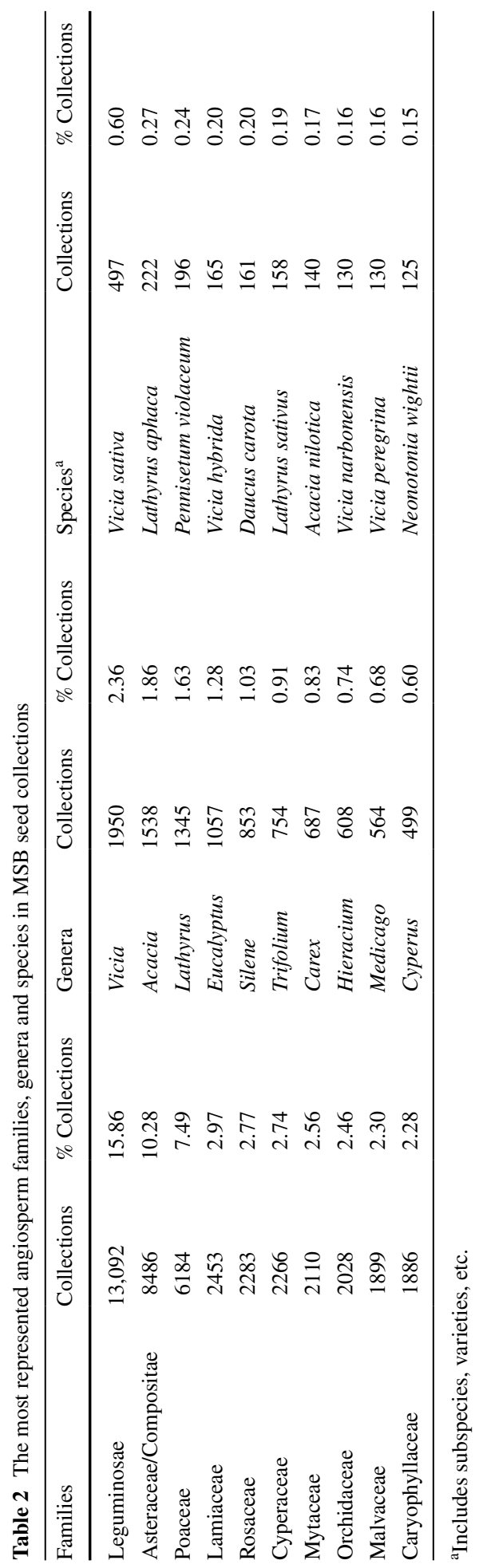


Table 3 The representativeness of angiosperm families and genera conserved at MSB

Naturally occurring genera and species Total number of families or genera for which the naturally occurring genera or species have been conserved at the MSB in percentage classes

\begin{tabular}{|c|c|c|c|c|c|c|c|}
\hline Plant List (2013) & & MSB holdings & $\%$ Conserved at MSB & $1-25 \%$ & $26-50 \%$ & $51-75 \%$ & $>75 \%$ \\
\hline \multicolumn{8}{|c|}{ Number of genera per family } \\
\hline $1-50$ & 344 & 265 & \multirow[t]{6}{*}{ Families } & 33 & 82 & 49 & 101 \\
\hline $51-100$ & 29 & 28 & & 5 & 15 & 8 & 0 \\
\hline $101-150$ & 12 & 12 & & 2 & 4 & 6 & 0 \\
\hline $151-200$ & 7 & 7 & & 3 & 3 & 1 & 0 \\
\hline$>200$ & 12 & 12 & & 2 & 7 & 3 & 0 \\
\hline Total & 404 & 324 & & 45 & 111 & 67 & 101 \\
\hline \multicolumn{8}{|c|}{ Number of species per family } \\
\hline $1-50$ & 191 & 121 & \multirow[t]{8}{*}{ Families } & 46 & 47 & 6 & 22 \\
\hline $51-100$ & 40 & 34 & & 26 & 6 & 2 & 0 \\
\hline $101-500$ & 69 & 66 & & 58 & 7 & 0 & 0 \\
\hline $501-1000$ & 34 & 34 & & 32 & 2 & 0 & 0 \\
\hline $1001-5000$ & 57 & 57 & & 53 & 2 & 1 & 0 \\
\hline $5001-10,000$ & 6 & 5 & & 5 & 0 & 0 & 0 \\
\hline$>10,000$ & 5 & 5 & & 5 & 0 & 0 & 0 \\
\hline Total & 402 & 322 & & 225 & 64 & 9 & 22 \\
\hline \multicolumn{8}{|c|}{ Number of species per genera } \\
\hline $1-50$ & 13,348 & 4394 & \multirow[t]{6}{*}{ Genera } & 1686 & 1384 & 323 & 1001 \\
\hline $51-100$ & 552 & 411 & & 322 & 71 & 13 & 5 \\
\hline $101-500$ & 560 & 475 & & 393 & 63 & 6 & 1 \\
\hline $501-1000$ & 45 & 42 & & 36 & 2 & 0 & 1 \\
\hline$>1000$ & 20 & 19 & & 17 & 0 & 1 & 0 \\
\hline Total & 14,525 & 5341 & & 2454 & 1520 & 343 & 1008 \\
\hline
\end{tabular}

The representativeness of each angiosperm family was estimated as the percentage of genera and species conserved within the family against the total number of naturally occurring genera and species described for the family. Likewise, the representativeness of each angiosperm genus was estimated as the percentage of species conserved at MSB within the genus against the total number of naturally occurring species described for the genus. The total number of accepted genera and species described per family and accepted species described per genus were taken from The Plant List (2013) considering the confidence level and review status of names. Doubtful data were excluded from the analysis. Full dataset available in Appendix 1 and Supplement 1. Example: 101 (highlighted in italic) shows that 101 families of plants containing 1-50 genera have $>75 \%$ of their naturally occurring genera conserved at the MSB

$(44,130)$. The hotspots with the greatest number of MSB collections are the Mediterranean Basin (13,020), Madagascar and the Indian Ocean Islands (4027), the Cape Floristic Region (3016), Southwest Australia (2935) and the Caucasus (2753). Hotspots with the lowest number of collections are Polynesia-Micronesia (9), the Western Ghats and Sri Lanka (12), the East Melanesian Islands (26), New Caledonia (33) and the Philippines (62).

\section{Vulnerability to extinction}

The representativeness of taxa in the MSB that are extinct, rare or vulnerable to extinction and taxa with a lower risk of extinction at global and/or national scales are given in 
Table 4 Overview of seed collections conserved at MSB from each bio-geographic region

\begin{tabular}{lccrrr}
\hline Bio-geographic region & Collections & Families & Genera & Species & Taxa $^{\text {a }}$ \\
\hline Africa & 21,109 & 235 & 2256 & 9998 & 10,677 \\
Antarctic & 388 & 40 & 104 & 177 & 178 \\
Asia-temperate & 15,868 & 178 & 1653 & 6649 & 6938 \\
Asia-tropical & 1145 & 104 & 352 & 575 & 589 \\
Australasia & 12,107 & 183 & 1281 & 8582 & 9068 \\
Europe & 17,155 & 143 & 1028 & 5390 & 6066 \\
Northern America & 8662 & 194 & 1500 & 5476 & 5738 \\
Southern America & 3908 & 172 & 974 & 2342 & 2435 \\
Pacific & 63 & 27 & 51 & 56 & 56 \\
Unknown & 2151 & 134 & 581 & 1283 & 1335 \\
\hline
\end{tabular}

Cultivated collections inherited the geographic origin of the wild plant population from which they were propagated or regenerated. The total number of collections, families, genera, species and taxa originated from each bio-geographic region is presented based on geographic origin data

${ }^{\mathrm{a}}$ Includes species, sub species, varieties, etc.

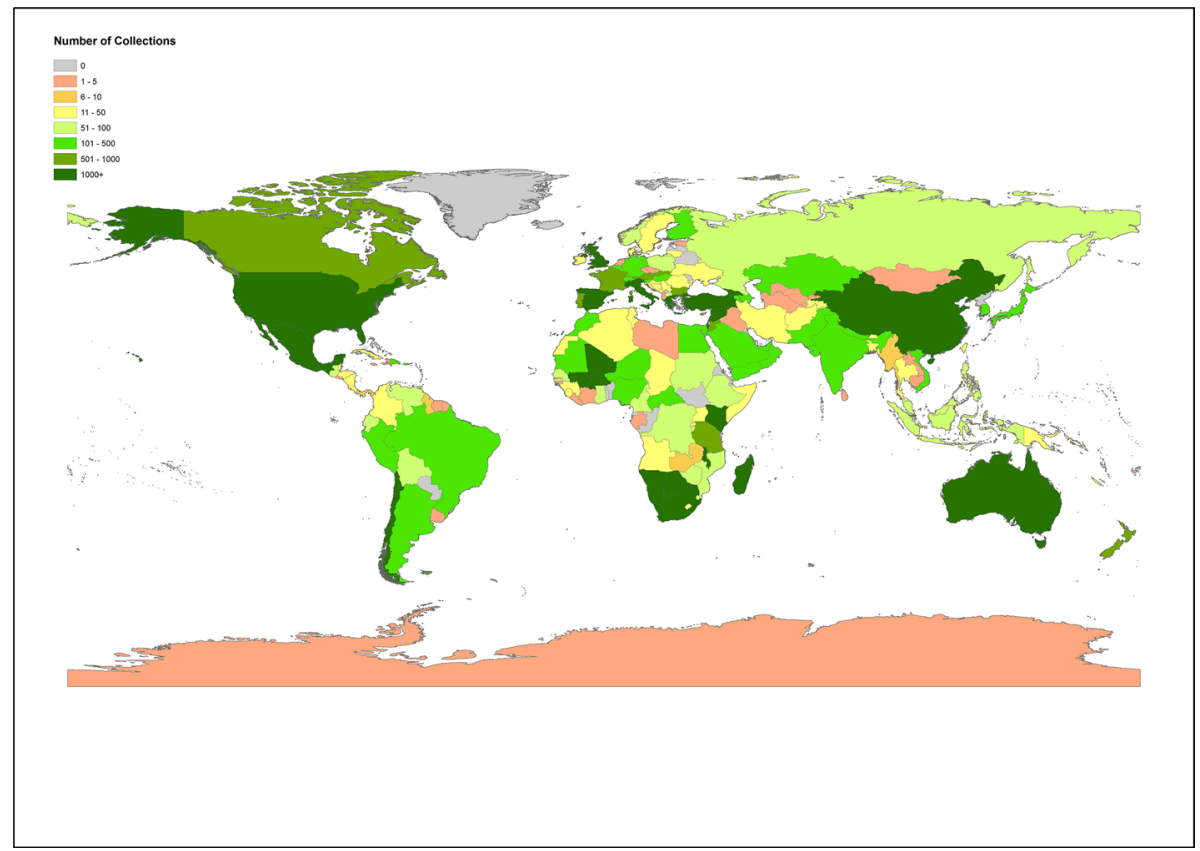

Fig. 1 Geographic origin of MSB collections. Cultivated collections inherited the geographic origin of the wild plant population from which they were propagated or regenerated. Total number of collections are shown according to different size classes. (Color figure online)

Tables 5 and 6. When compared with IUCN (2016) global assessments, MSB conserved at least $5.31 \%$ of taxa, representing nearly 1600 collections, which are declared as extinct or vulnerable to extinction (EW, CR, EN and VU). This includes seven of 36 taxa which 


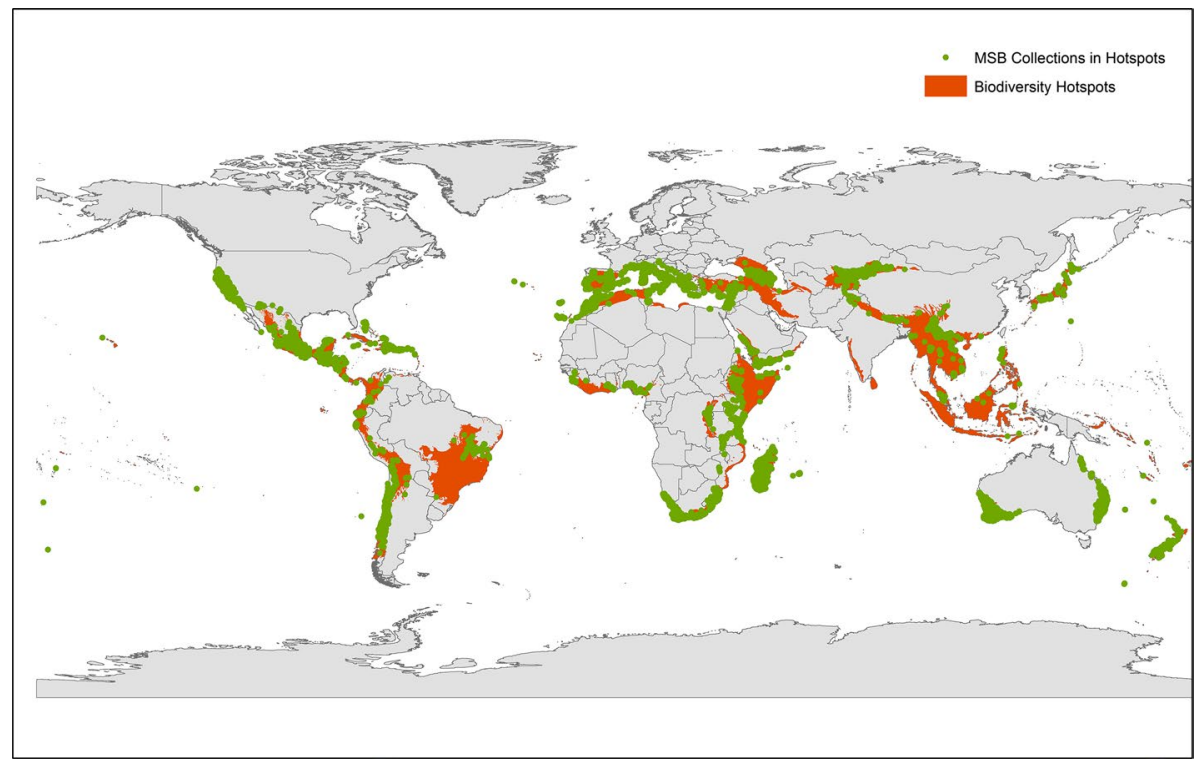

Fig. 2 MSB collections originating from 35 biodiversity hotspots. Cultivated collections inherited the geographic origin of the wild plant population from which they were propagated or regenerated. Collections with missing coordinates but originating from biodiversity hotspots according to locality data are not shown. The complete list of collections is given in Appendix 2. (Color figure online)

are declared as extinct in the wild (Table 7). For those taxa declared as having a lower risk of extinction, MSB collections include $23.19 \%$ taxa, represented by over 7400 collections. Nearly $10 \%$ of taxa (1487 out of 14,998) that are declared as globally rare in Walter and Gillett (1998) are conserved at the MSB, representing over 2700 collections. At the national scale, the MSB conserved at least $6.93 \%$ of taxa (over 3175 collections) that are declared as extinct, rare or vulnerable to extinction nationally in at least one country according to the National Red Lists (2016). In total, at least $10 \%$ of taxa (3801 out of 39,669 ) conserved at MSB, represented by over 6703 collections ( $>8 \%$ of total holdings), are either extinct, rare or vulnerable to extinction at the global and/or national scale.

\section{Uniqueness and irreplaceability}

Twenty percent of MSB taxa (7764 out of 39,669), representing 13\% of collections $(11,064$ out of 82,556), are endemic or near endemic at the country or territory scale.

At least $21 \%$ of angiosperm families conserved ( 70 out of 331 ) are taxonomically distinct at the species level, and 58\% of angiosperm families conserved (191 out of 331) are taxonomically distinct at the genus level, with 11 of the families (Biebersteiniaceae, Cephalotaceae, Drosophyllaceae, Eucommiaceae, Gomortegaceae, Lanariaceae, Plocospermataceae, Quillajaceae, Scheuchzeriaceae, Setchellanthaceae and Strasburgeriaceae) with only one genera and species described in nature (Table 8; Appendix 1). At least $49.6 \%$ of angiosperm genera conserved at MSB (2843 out of 5723) are taxonomically distinct with only a few species (up to 10) occurring in nature (Supplement 1). 


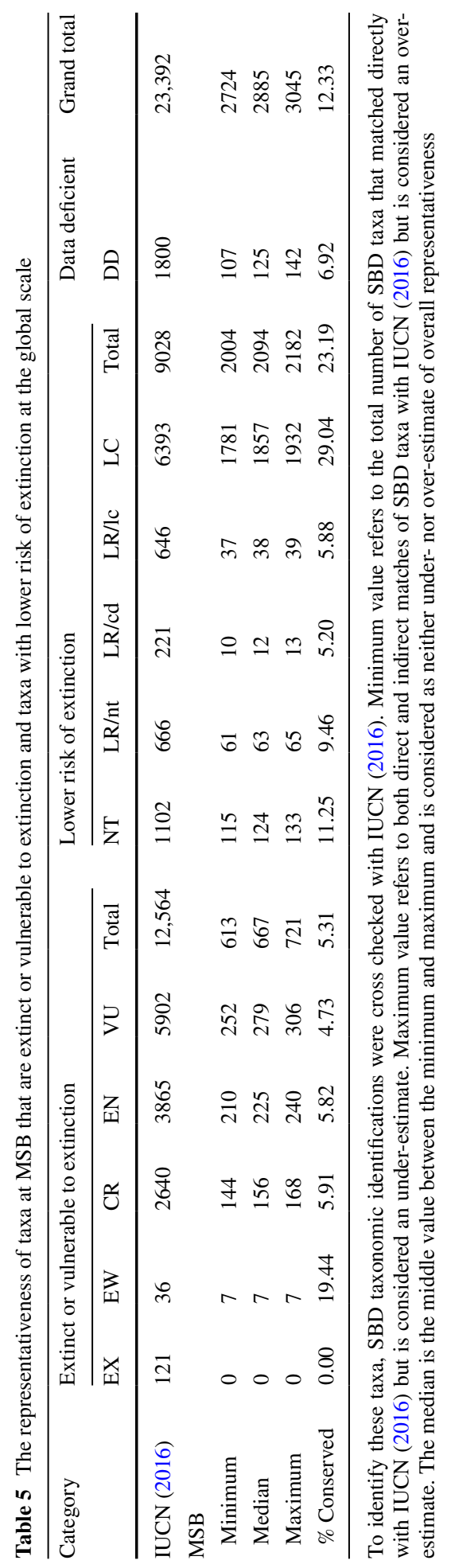




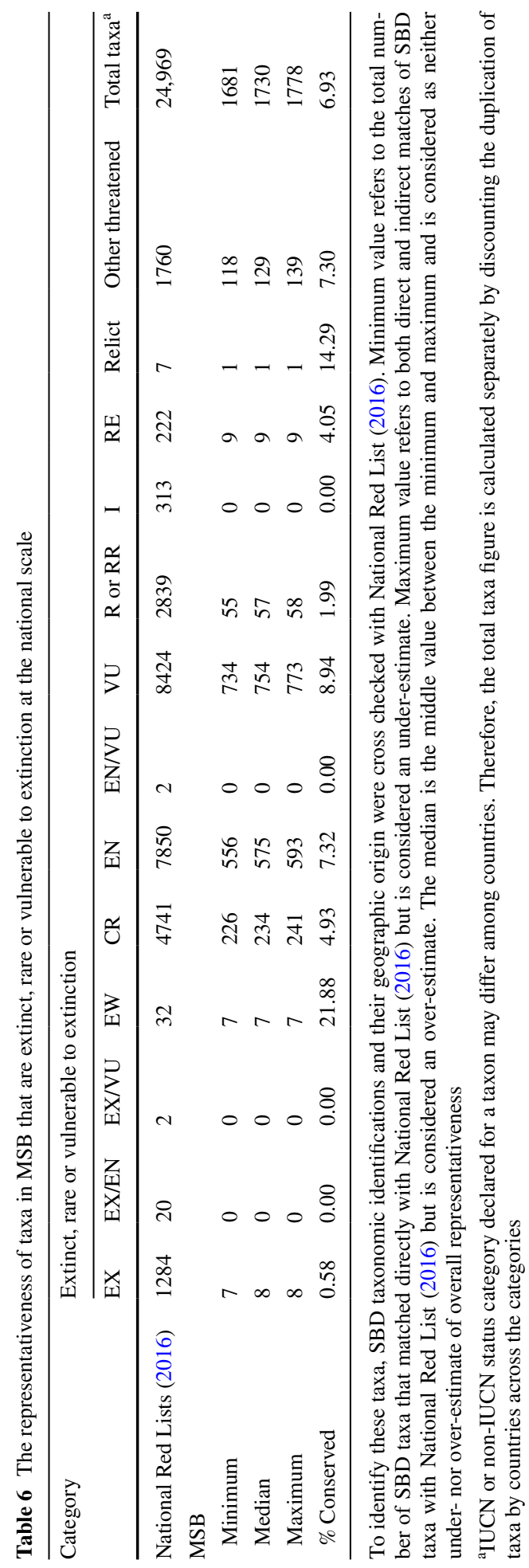


Table 7 Taxa conserved at MSB that are declared as extinct in the wild (EW) by IUCN (2016)
Table 8 Taxonomic singularity and rarity of MSB seed collections at family level

\begin{tabular}{ll}
\hline Family & Taxa \\
\hline Nymphaeaceae & Nymphaea thermarum \\
Poaceae/Gramineae & Bromus bromoideus \\
Poaceae/Gramineae & Bromus interruptus \\
Primulaceae & Lysimachia minoricensis \\
Solanaceae & Brugmansia arborea \\
Malvaceae & Trochetiopsis erythroxylon \\
Thecaceae & Franklinia alatamaha \\
\hline
\end{tabular}

Taxonomic singularity

Number of angiosperm families conserved at MSB

Number of genera or species For genera For species described from The Plant List (2013)

\begin{tabular}{lrc}
\hline 1 & 70 & 11 \\
2 & 25 & 19 \\
3 & 27 & 8 \\
4 & 22 & 6 \\
5 & 11 & 5 \\
6 & 9 & 5 \\
7 & 7 & 7 \\
8 & 8 & 6 \\
9 & 6 & 0 \\
10 & 6 & 3 \\
Total & 191 & 70 \\
\hline
\end{tabular}

The number of genera and species for angiosperm families was obtained from The Plant List (2013) considering the confidence level and review status of names to identify less diversified families (with up to 10 genera or 10 species), then their representation at MSB was measured and expressed as taxonomic singularity to identify taxonomic rarity. Doubtful data were excluded from the analysis (see Appendix 1)

\section{Natural capital value}

The majority of MSB collections (49\%, 40,430 out of 82,556) have at least one natural capital value and these represent $32 \%$ of MSB taxa $(12,643$ out of 39,669). From a total of 99 CWR genera, 81\% (80 genera) are conserved at the MSB. At least 11.3\% (9294 out of 82,556) of MSB collections can be considered as CWR sensu lato, represented by 1933 taxa. Of the 4229 CWR sensu stricto taxa compiled from reference sources, $22 \%$ (953) are stored at the MSB, representing $8.7 \%$ of MSB collections (7160 out of 82,556).

\section{Population value}

The majority of taxa $(74 \%, 29,326$ out of 39,669$)$ and collections $(78 \%, 64,501$ out of $82,556)$ stored at the MSB are represented by sensu lato $3 \mathrm{E}$ taxa. Two-3E taxa are those 
that meet two of the three criteria of endemic, endangered or economic, we found that $16 \%$ of MSB taxa (6322 out of 39,669), represented by over 12,220 collections (15\%), fall under this category. Sensu stricto $3 \mathrm{E}$ taxa are those that are endemic, endangered and of economic value i.e. meet all 3Es; 315 MSB taxa represented by 566 collections fall under this category.

\section{Germplasm quality}

Figure 3 illustrates the availability of data for MSB collections. A high percentage of collections ( $>95 \%$ ) have taxonomy (Latin plant name) and geographic data at least at country level, followed by geo-coordinates $(88 \%)$, habitat $(87 \%)$, altitude $(79 \%)$ and population data $(49-71 \%)$. Plant taxonomy of $89 \%$ of collections $(73,600)$ are verified either by a field expert, RBG Kew herbarium or another institute in the UK or elsewhere.

Seed quantity data are available for $95 \%$ of collections $(78,768$ collections out of 82,556 ), with $34 \%$ of them represented by more than 5000 potentially viable seeds per collection, whereas $25 \%$ are represented by $<501$ potentially viable seeds (Fig. 4). About 56,595 collections processed at the MSB are also duplicated in another seed bank in the $\mathrm{UK}$ and/or in the country of origin.

For the last round of viability tests carried out for seed collections, germination data are available for $70 \%$ of collections $(57,658$ out of 82,556$)$ and seed viability data are available for $69 \%$ collections $(57,141$ out of 82,556$)$. Of these collections, $47 \%$ and $65 \%$ respectively showed more than $90 \%$ germination and viability and $21 \%$ and $11 \%$ respectively showed less than $50 \%$ germination and viability (Fig. 5). Of the tested collections, 7.7\% (4457 out of 57,658 ) showed $0 \%$ germination and $3.2 \%$ (1861 out of 57,141$)$ showed $0 \%$ viability. As viability percentages were estimates calculated using cut-tested results of non-germinated

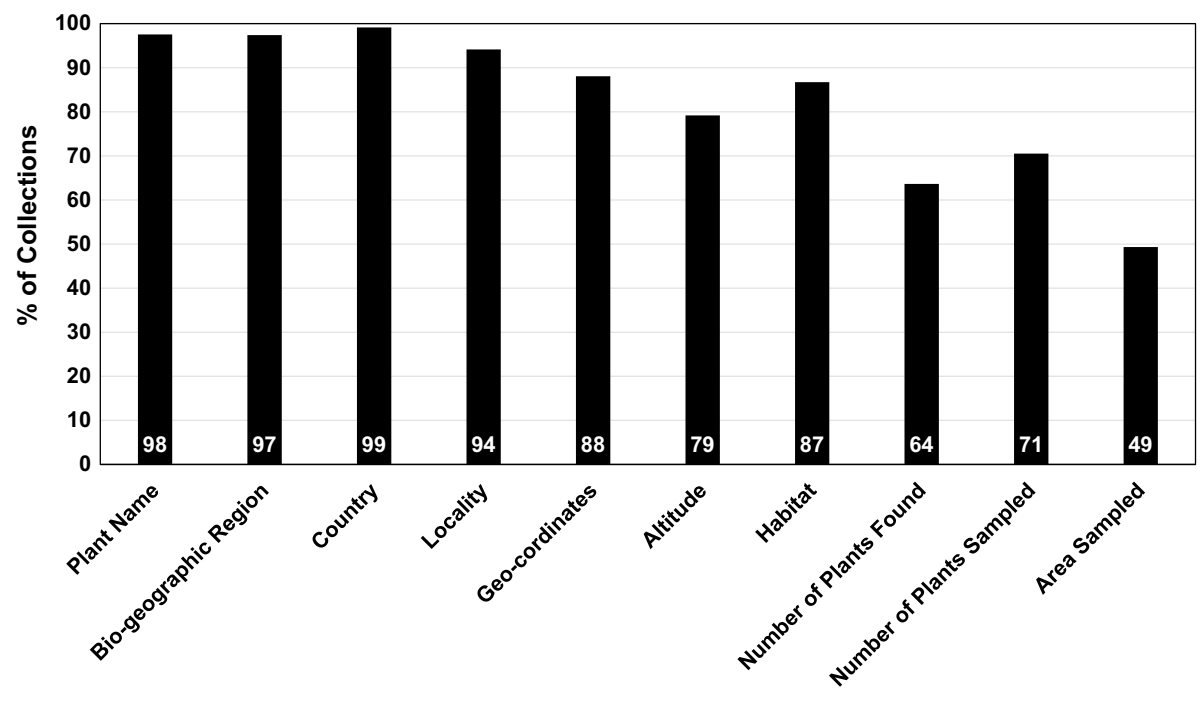

Indicators

Fig. 3 Availability of key data for MSB collections. These includes taxonomy (plant name), geography (bio-geographic region, country, locality, geo-coordinates and altitude), habitat and population (number of plants found and sampled, and area sampled) 


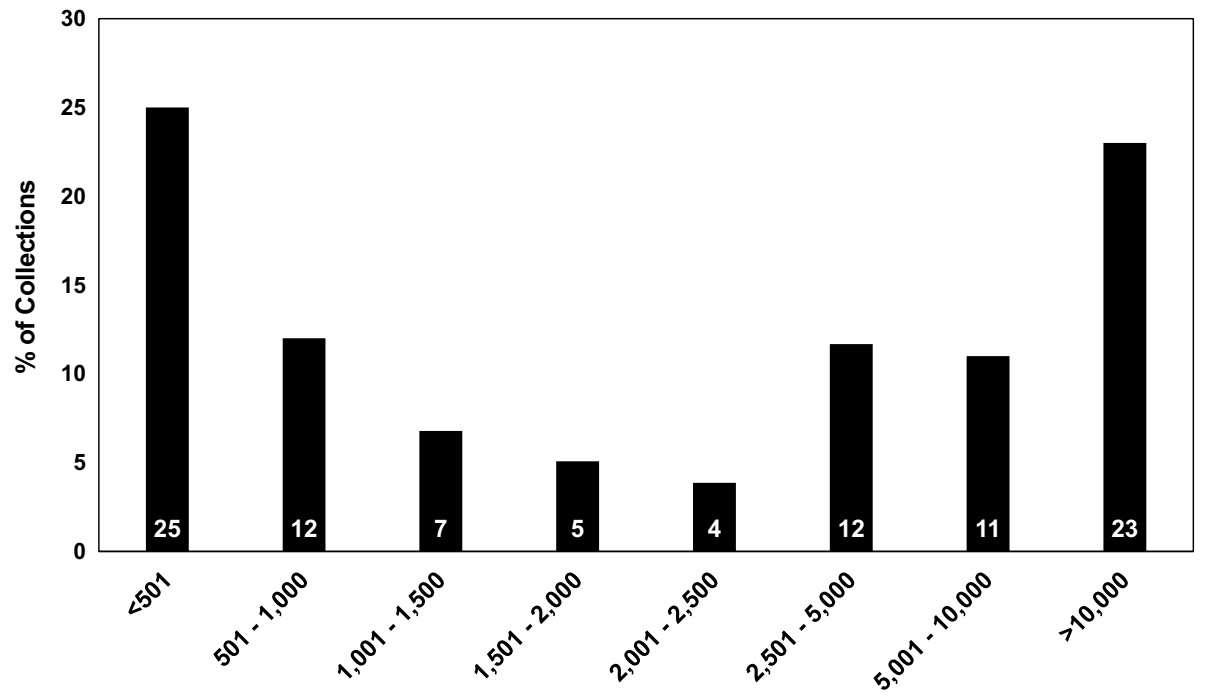

Potentially Viable Seed Quantity

Fig. 4 Potentially viable seed quantity. Percentage of MSB collections in different size classes of estimated number of viable seeds are illustrated taking into account the results of X-rayed or cut-tested samples of dry seeds

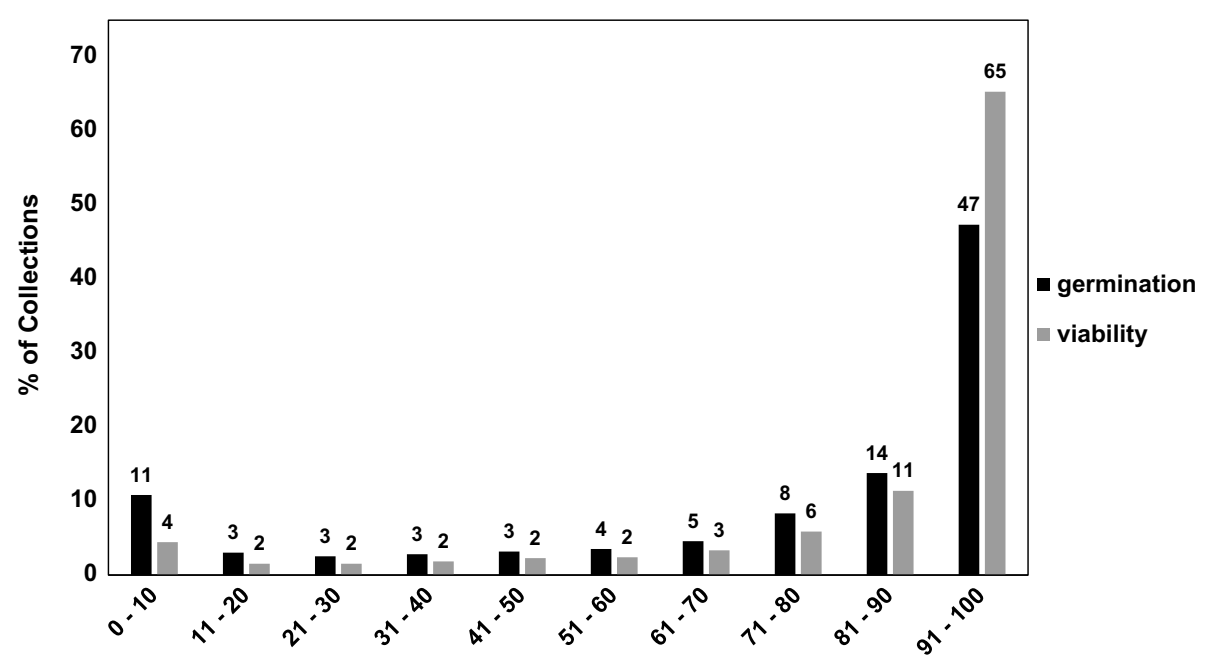

Germination \% or Viability \%

Fig. 5 Seed germination and viability. Percentage of MSB collections in different size classes of germination and viability percentage are illustrated for the last round of germination tests carried out at the MSB. The highest percentages achieved for germination and viability are considered 
seeds, collections with $0 \%$ germination and viability will be further assessed using experimental controls or Tetrazolium Chloride stain.

\section{Use of collections}

During January 2000-March 2017, a total number of 11,182 seed samples representing 6759 collections, 4811 taxa (including subspecies and varieties) and 200 families were supplied to over 410 organizations across 57 countries (includes RBG Kew and UK). At least $8.2 \%$ of collections and $12.1 \%$ of taxa were distributed globally for a diverse range of uses in research (75\%), conservation (13\%), education (2\%) and display (1\%). Details of use for $9 \%$ of samples are unknown. Seed samples supplied for research were used across at least 80 pure and applied science disciplines including agriculture, horticulture and archaeology. Those supplied for conservation were used in a range of programs including: habitat restoration and enrichment; species re-introduction or recovery; developing or improving botanic garden, arboretum or nursery collections; regeneration; propagation; breeding; biological control; livelihood programmes; and ex-situ conservation. Samples supplied for education were used during course work and workshops at educational institutes including schools and universities and those supplied for national and international displays were used to raise public awareness of plant conservation. The most distributed taxa were (number of samples distributed in brackets): Lotus corniculatus (71); Brassica oleracea (60); Trifolium repens (48); Lolium perenne (36); Sorghum arundinaceum (33); Beta vulgaris (33); Daucus carota (32); Dactyloctenium aegyptium (31); Trifolium pratense (30); and Chenopodium album (30).

\section{Discussion}

Plant conservation by seed banking orthodox species at RBG Kew contributes towards RBG Kew's Science Strategy (RBG Kew 2015), Targets 8 and 9 of the GSPC and tackling the challenges of food security, sustainable energy, loss of biodiversity and climate change. This study highlights the following strengths of MSB holdings: a rich biological resource; substantial taxonomic diversity; wide geographic coverage; notable uniqueness and irreplaceability; significant natural capital and population value; and high quality germplasm. Seventy four percent of MSB taxa, representing $78 \%$ of collections, fall into one or more of three important categories: (1) endemic; (2) endangered at the national or global scale; and (3) of economic, ecological, social, cultural or scientific value. In addition, MSB holdings represent $81 \%$ of CWR genera.

The importance of these collections in the face of threats to global plant diversity cannot be overstressed. An estimated 369,434 species of angiosperms are known to science, and $21 \%$ of global plant species are currently threatened with extinction (Nic Lughadha et al. 2016; RBG Kew 2016). By focusing seed conservation efforts on endangered species RBG Kew's MSB is helping to conserve plant diversity that is most at risk of extinction. As many as $44 \%$ of all species of vascular plants are confined to 25 hotspots comprising only $1.4 \%$ of the land surface of the earth (Myers et al. 2000). Using these regions as collection foci has enabled RBG Kew to maximize its impact with limited resources, and effort continues to be directed to those hotspots currently under-represented in RBG Kew's collections. 
Despite the importance of the collections and the targeted approach, limitations to seed conservation remain. Challenges include: the absence of a red list or up to date, accurate information on threatened species for some partner countries; accessible data on the locality, phenology and identification of taxa; infrastructure for processing and storage of seeds; and skills enabling collection, handling and storage of seed (Smith 2007). The level of emphasis on which taxa are to be conserved is governed by the Access and Benefit Sharing Agreements (ABSA), the needs of project partners, the political, legal and administrative requirements of the regional, national or local government in question and the level of implementation of the CBD within a particular country or region (Cheyne 2003). Due to the current global financial crisis, the availability of monetary funds is another bottle neck for initiating conservation programmes. Lack of political will and funding are the biggest constraints preventing the achievement of Target 8 of GSPC (Smith 2007). An estimated $£ 50$ million was spent to secure $10 \%$ of world's flora during the first phase of ex situ conservation in RBG Kew's international programme (Smith 2007), representing about $£ 2100$ per plant species to guarantee its long-term ex situ seed conservation ( $\mathrm{Li}$ and Pritchard 2009).

Most importantly, only orthodox species whose seeds can survive considerable desiccation and freezing during ex situ conservation are bankable in traditional seed banks. Species adapted to hot, dry environments may have evolved longer lifespans in the dry state and are suitable to conserve in seed banks ( $\mathrm{Li}$ and Pritchard 2009). The world's drylands are home to an immense variety of plant life, with a high proportion of species producing orthodox seeds, and supporting approximately one-fifth of the world's population (far more than the tropical rain forests), as well as $50 \%$ of the world's livestock, and provide forage for both domestic animals and wildlife (van Slageren 2003). However, drylands are among the most threatened environments on Earth, with large areas being lost due to desertification each year (van Slageren 2003). As a result, the MSB initially focused its seed conservation efforts in drylands.

Representation of plant taxa in gene banks is also subjected to species, species-area, hotspot and infrastructure biases that result in over- or under- representing certain taxa (Hijmans et al. 2000). Under representation of threatened taxa may be linked to geographic rarity or recalcitrant seeds. Families with a high incidence of recalcitrant species which are less likely to be conserved in conventional seed banks are Fagaceae, Lauraceae, Sapotaceae, Moraceae, Clusiaceae, Sapindaceae (including Aceraceae), Arecaceae (= Palmae), Myrtaceae, Annonaceae, Rurtaceae, Anarcardiaceae, Dipterocarpaceae, Meliaceae and Rhizophoraceae (Dickie and Pritchard 2002). Some wild species have been found to produce seeds that are extremely short lived in traditional seed bank storage and cryopreservation may be the only resource to ensure the effective ex situ seed conservation of such species (Li and Pritchard 2009; Hay and Probert 2013). Li and Pritchard (2009) highlighted the need to increase our effort at developing ex situ conservation approaches for plants, particularly those from biodiversity hotspots with recalcitrant seeds.

Placing a monetary value on conservation collections is difficult. A recent estimate suggests that the potential value of benefits from CWR traits of the MSB's 29 current priority crops alone amounts to approximately $\$ 120$ billion (PwC 2013). Economic assessment is extraordinarily difficult beyond the main crops, particularly for species not yet fully characterised for traits of societal value (Li and Pritchard 2009). If CWR of 29 crops alone are worth $\$ 120$ billion, the entire MSB holdings of 39,669 taxa can be considered as a very successful output of a global ex situ conservation program, and an extremely valuable biological resource. 
MSB collections and associated data are already being used by partners to restore populations of wild plants (South Africa), to manage damaged ecosystems (Madagascar), to rehabilitate degraded lands (Burkina Faso and Australia), to develop opportunities for the sustainable use of plants by local communities (Kenya) and for scientific research (unpublished, RBG Kew). In addition, small quantities of MSB collections (usually 50 seeds) and associated data are also being supplied for use in conservation, research, education and display across the world. While the sample size is too small to support large-scale restoration projects, or research programmes requiring a large number of seeds, the importance of the collections for these areas cannot be overstated. The depth and breadth of information, knowledge and research outputs underpinning plant conservation being generated by MSB collections and associated data across the world is unparalleled. It is shared with policy makers, disseminated to the wider scientific community and general public through mainstream scientific literature, articles, conferences, social media and the RBG Kew website and those of our partners. Although compilation of a full list of research publications is beyond the scope of this paper, recent research studies that used MSB collections or their associated data include Colville et al. (2015), Díaz et al. (2016), Fernández-Marín et al. (2017), Mattana et al. (2017), Rodríguez-Arévalo et al. (2017), Seal et al. (2017), Ulian et al. (2017) and Wyse and Dickie (2017).

Our analysis was focused only on taxa conserved at the MSB and not on those stored only in seed banks of partner countries within the MSBP network. At present, it is difficult to assess the conservation value of taxa conserved within the whole network due to various constraints including lack of access to databases in partner countries. This is a problem that is being overcome by the MSBP Data Warehouse (http://brahmsonline.kew.org/msbp), an online BRAHMS database holding collection data from across the MSBP, and crucially, including data on collections not duplicated to the MSB. Further data analysis is essential across the MSBP network to underpin future collection activities to maximize the usefulness of collections while concentrating on gaps in threatened taxa, geographic representation and taxonomic diversity highlighted in our study, while identifying their suitability for conserving in conventional seed banks including cryopreservation.

Acknowledgements We thank all the funders, members of the Millennium Seed Bank Partnership, and staff of the Royal Botanic Gardens, Kew whose support has made the Millennium Seed Bank's collections possible. We also thank the anonymous reviewers and J.B. Dickie for providing constructive comments to improve the manuscript.

Open Access This article is distributed under the terms of the Creative Commons Attribution 4.0 International License (http://creativecommons.org/licenses/by/4.0/), which permits unrestricted use, distribution, and reproduction in any medium, provided you give appropriate credit to the original author(s) and the source, provide a link to the Creative Commons license, and indicate if changes were made.

\section{Appendix 1}

See Table 9. 


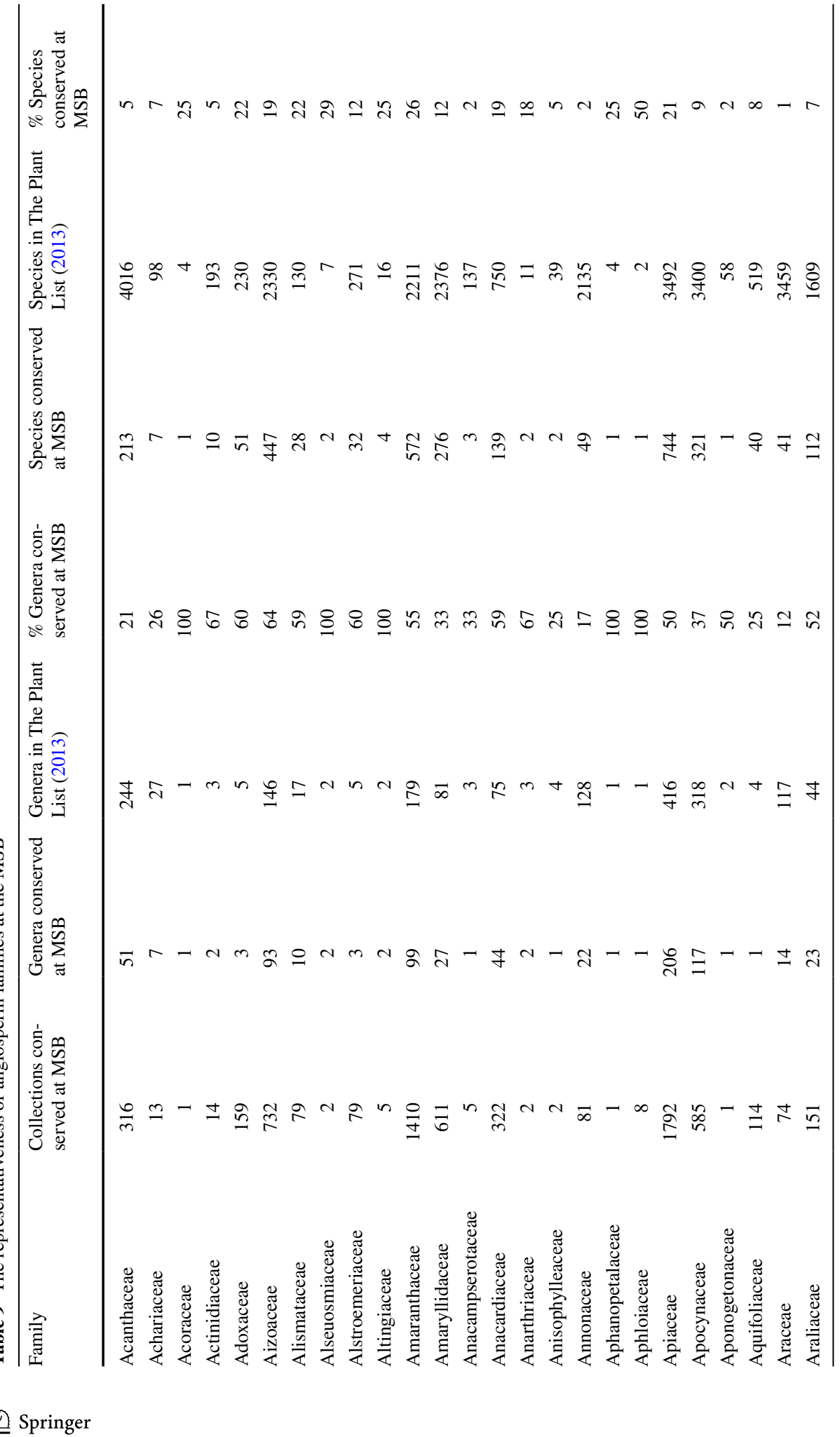




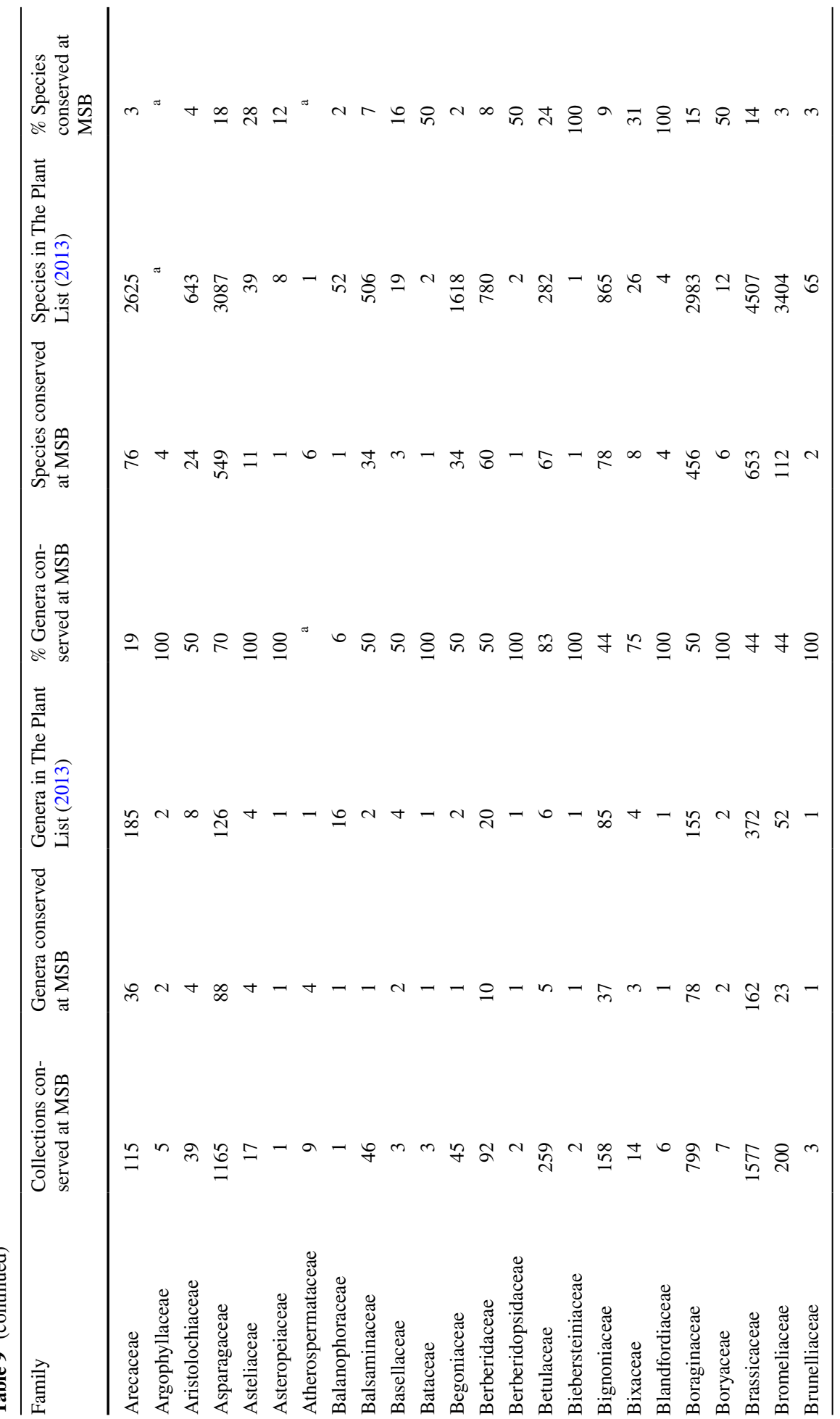




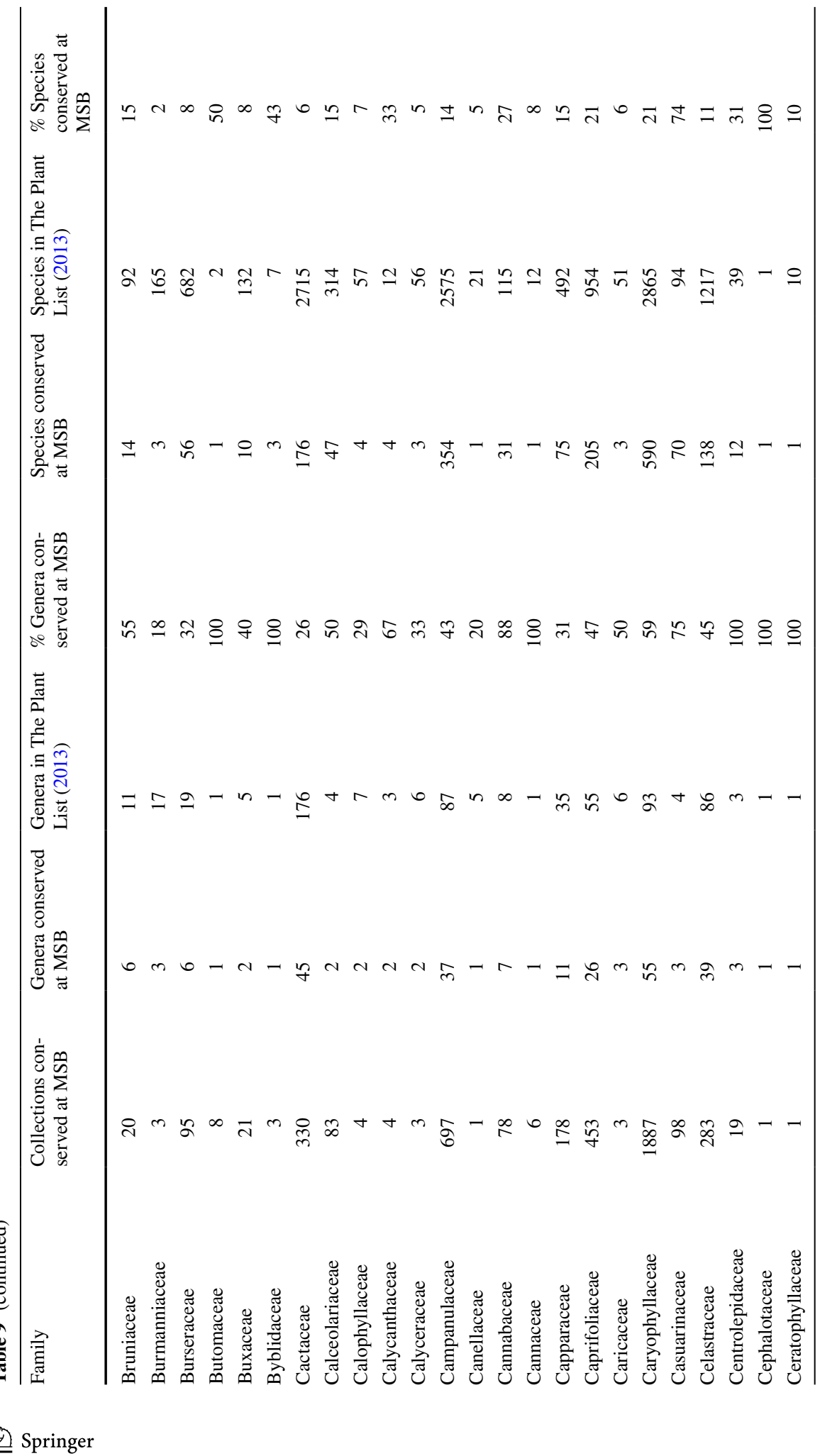




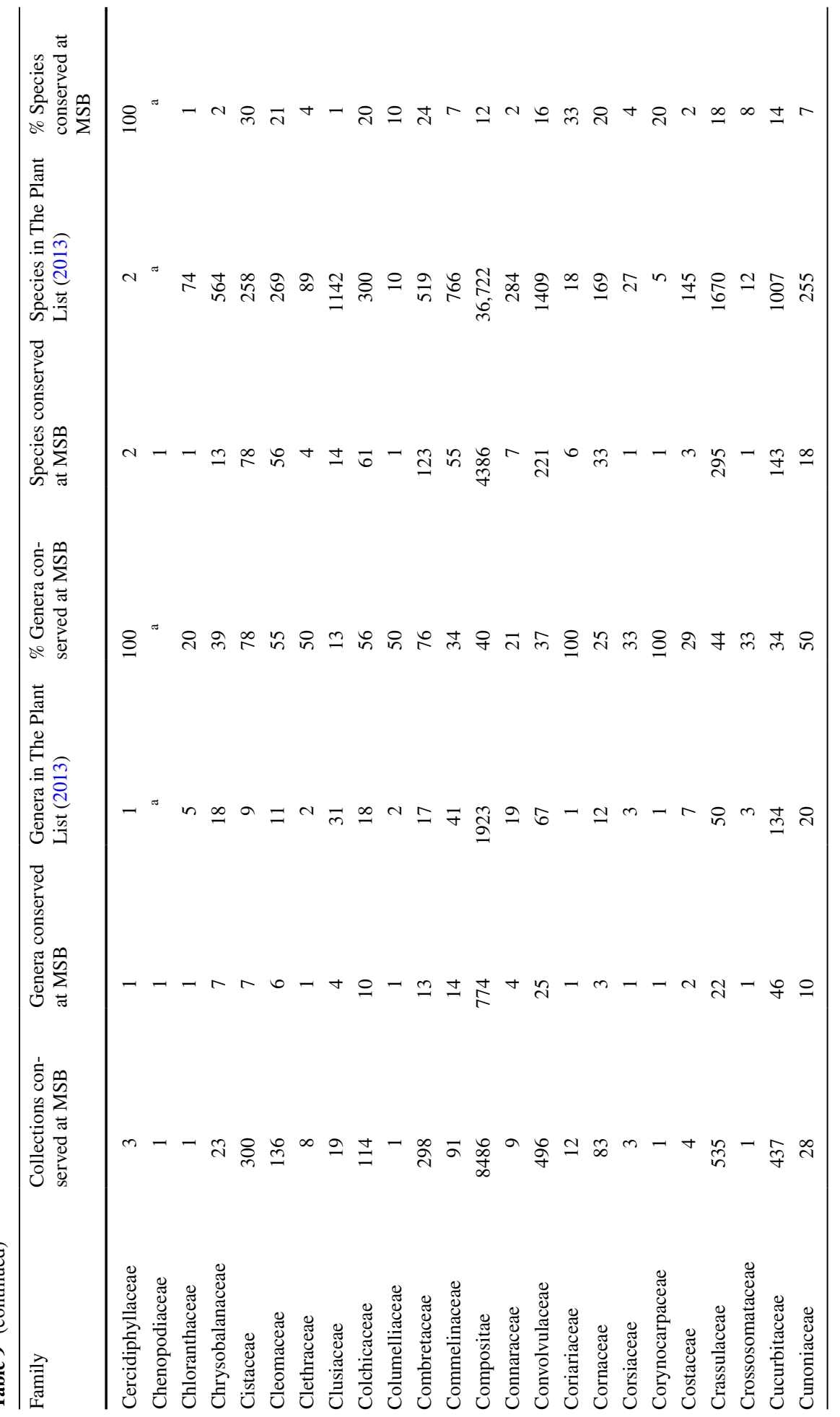




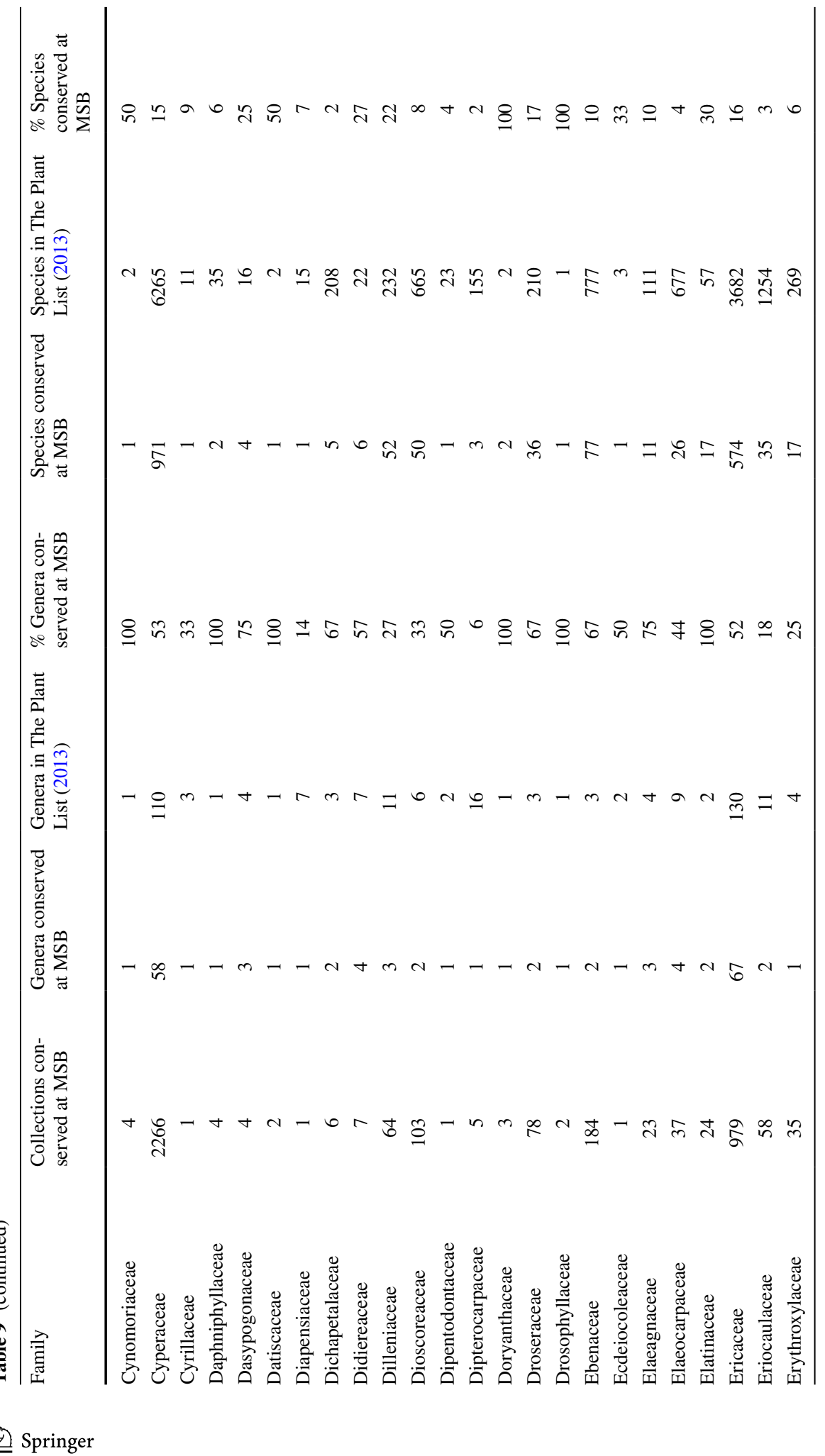




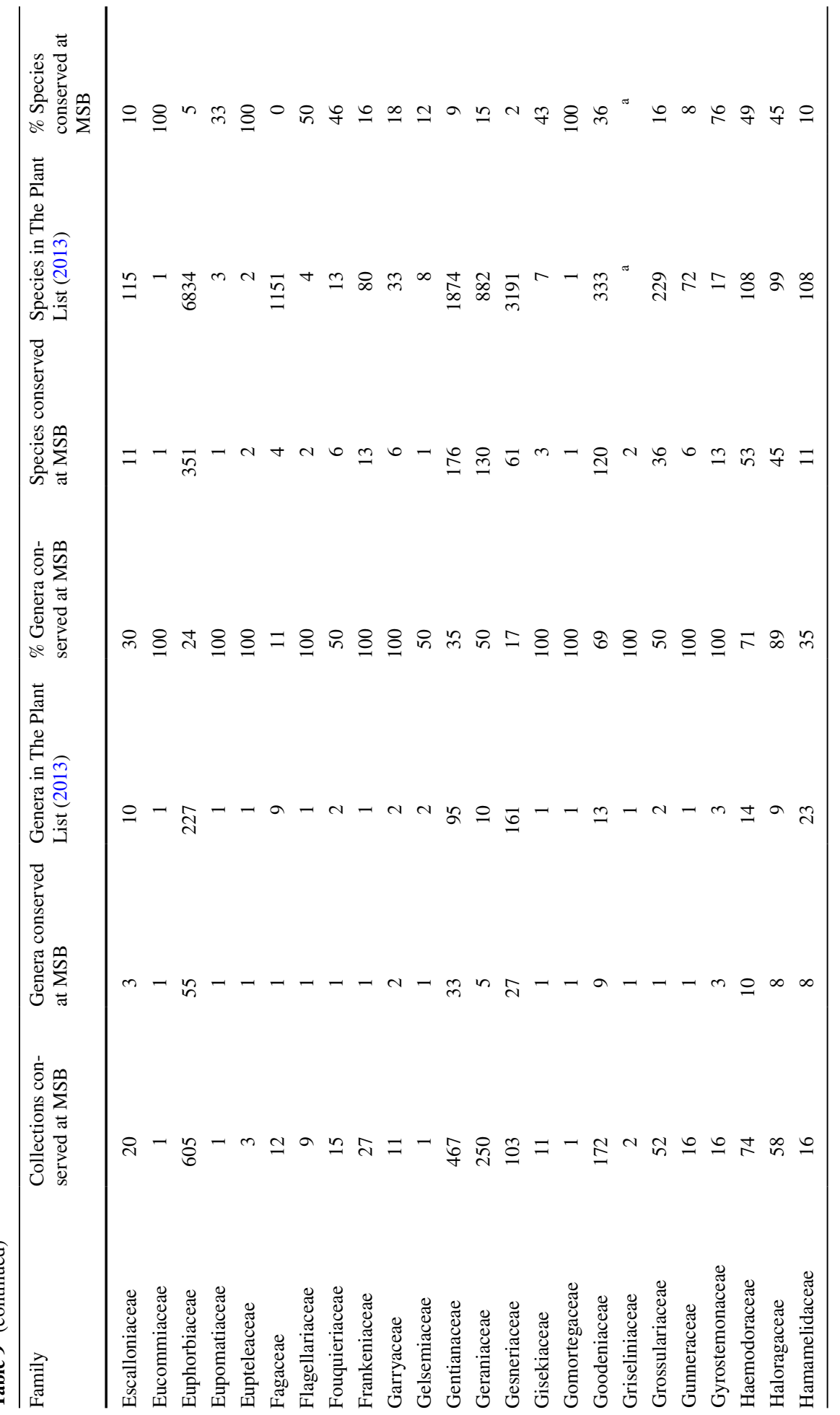




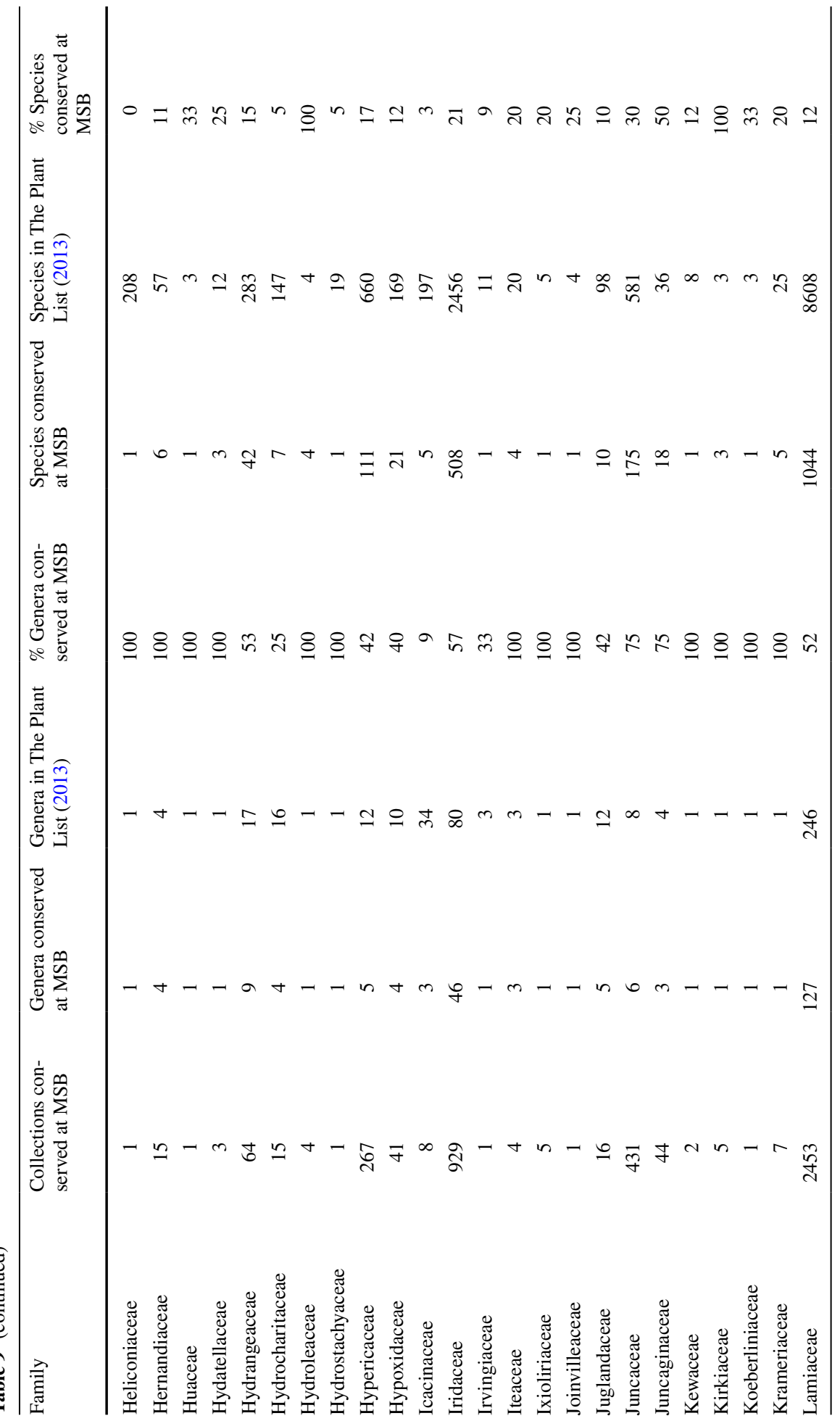




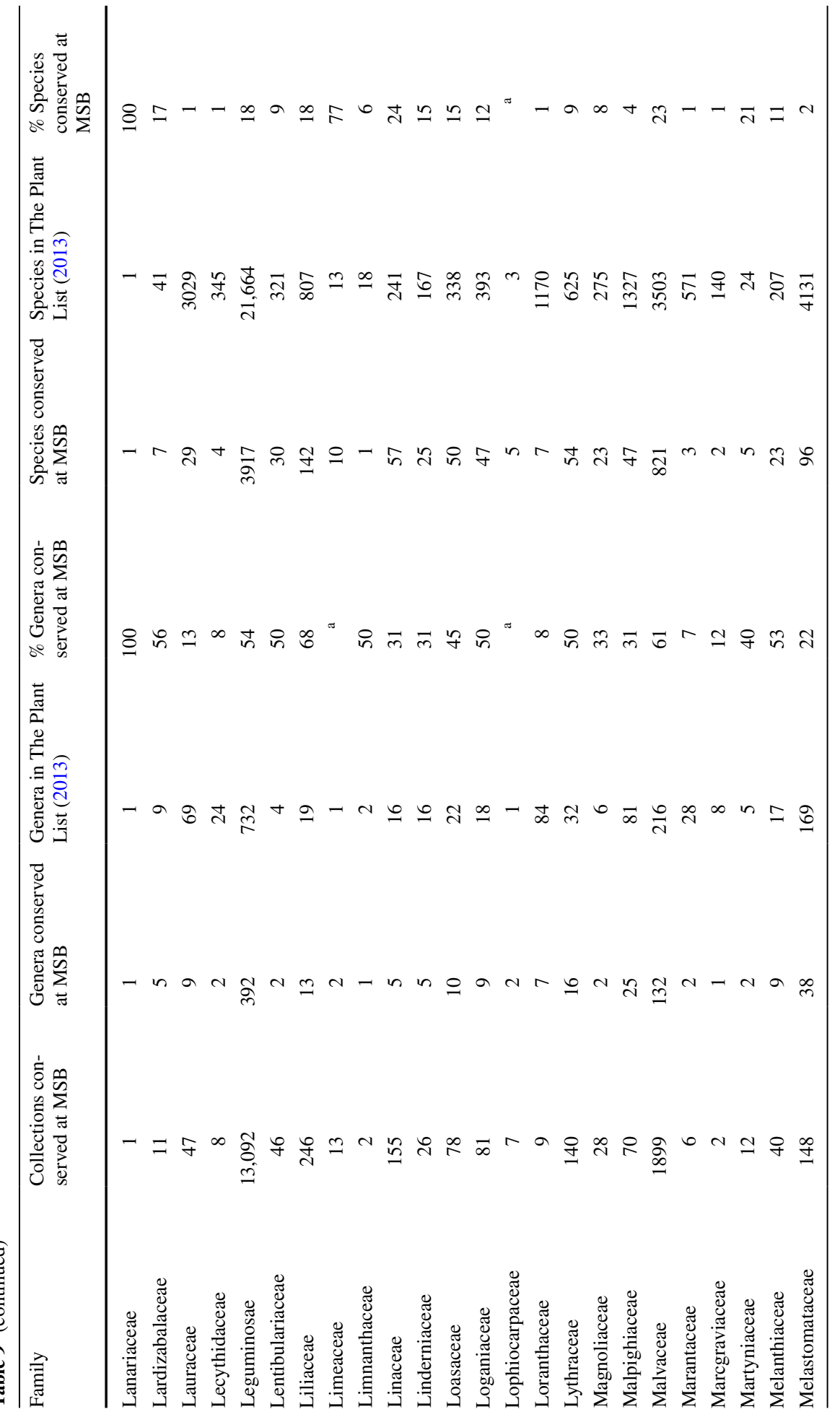




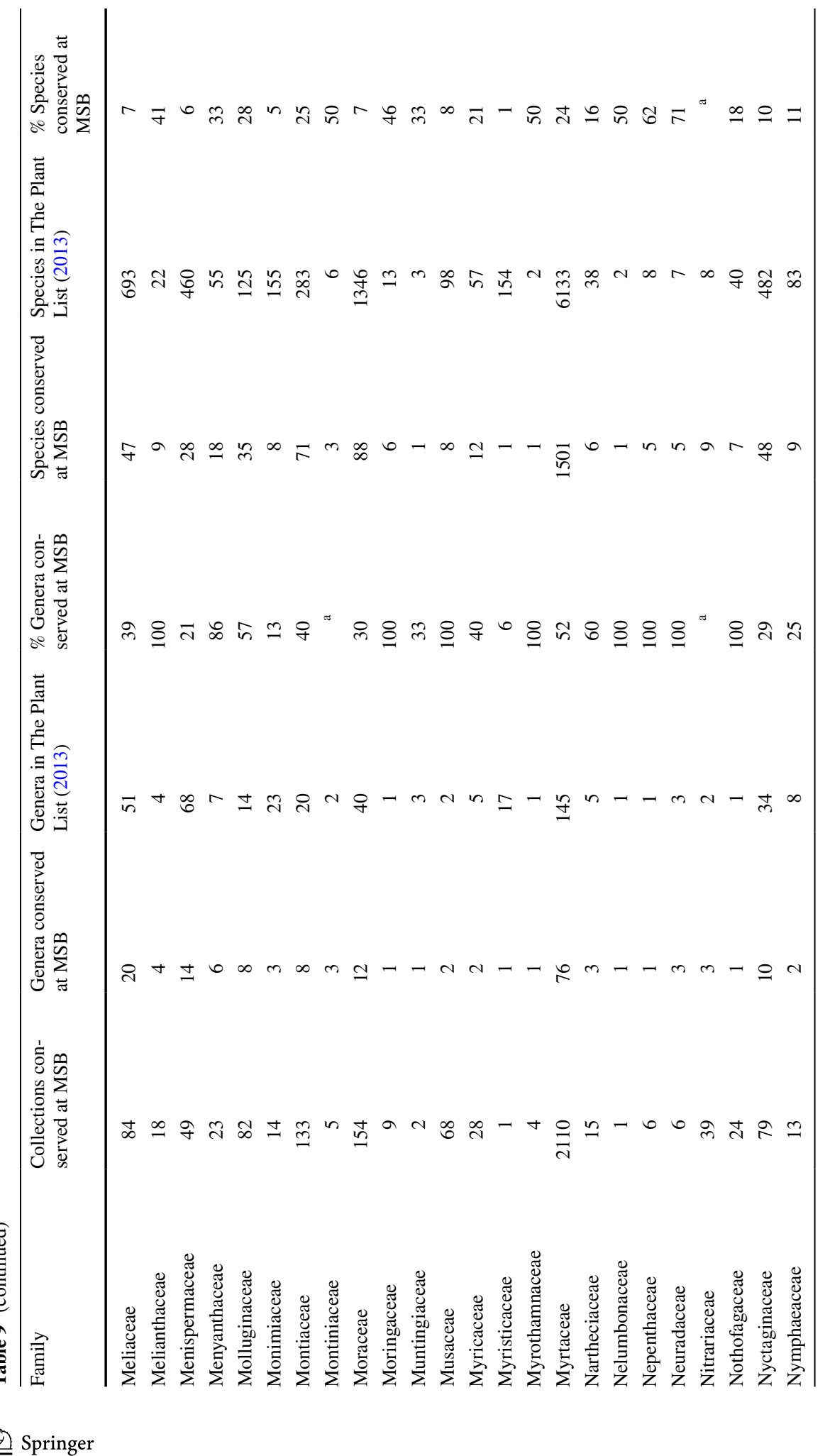




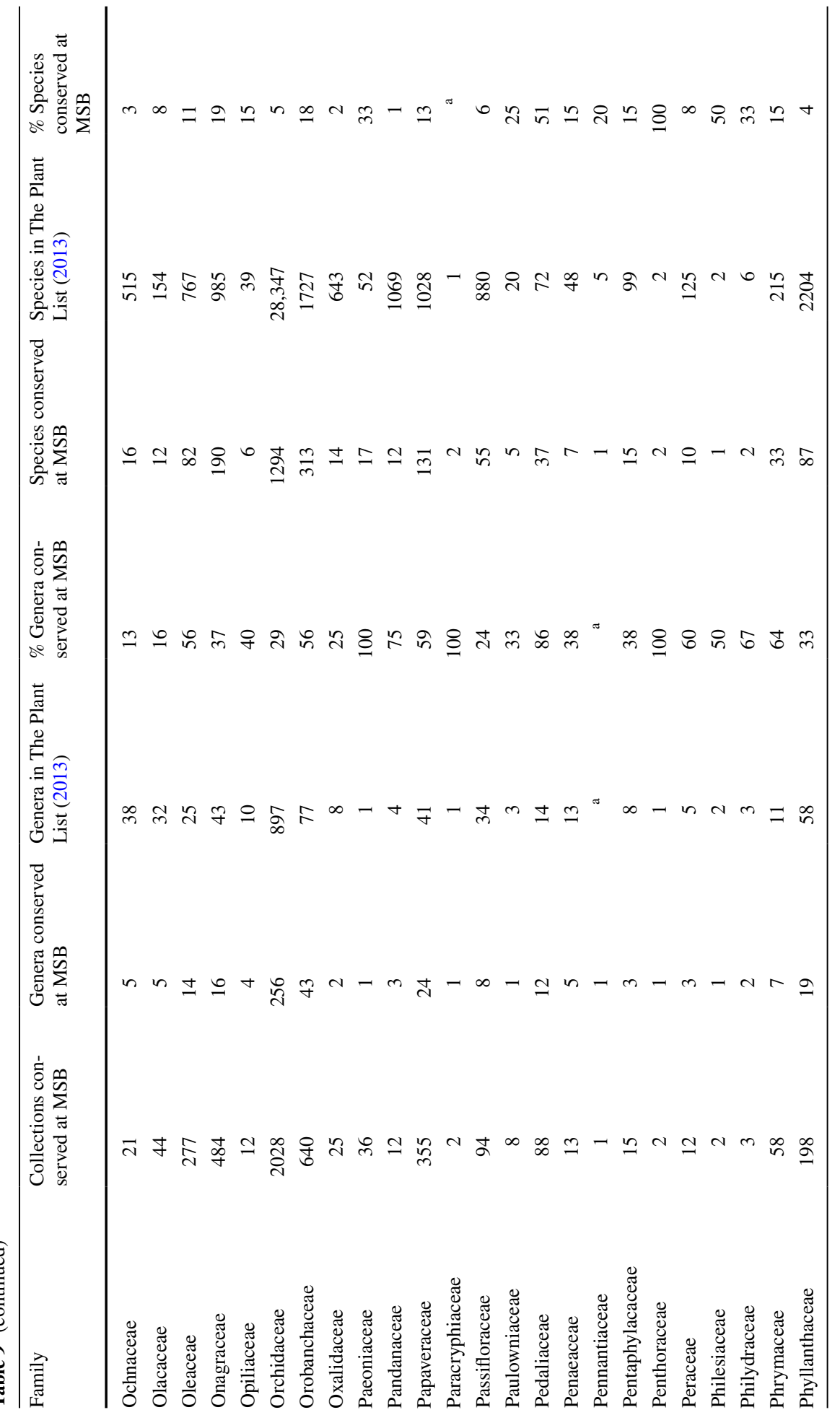




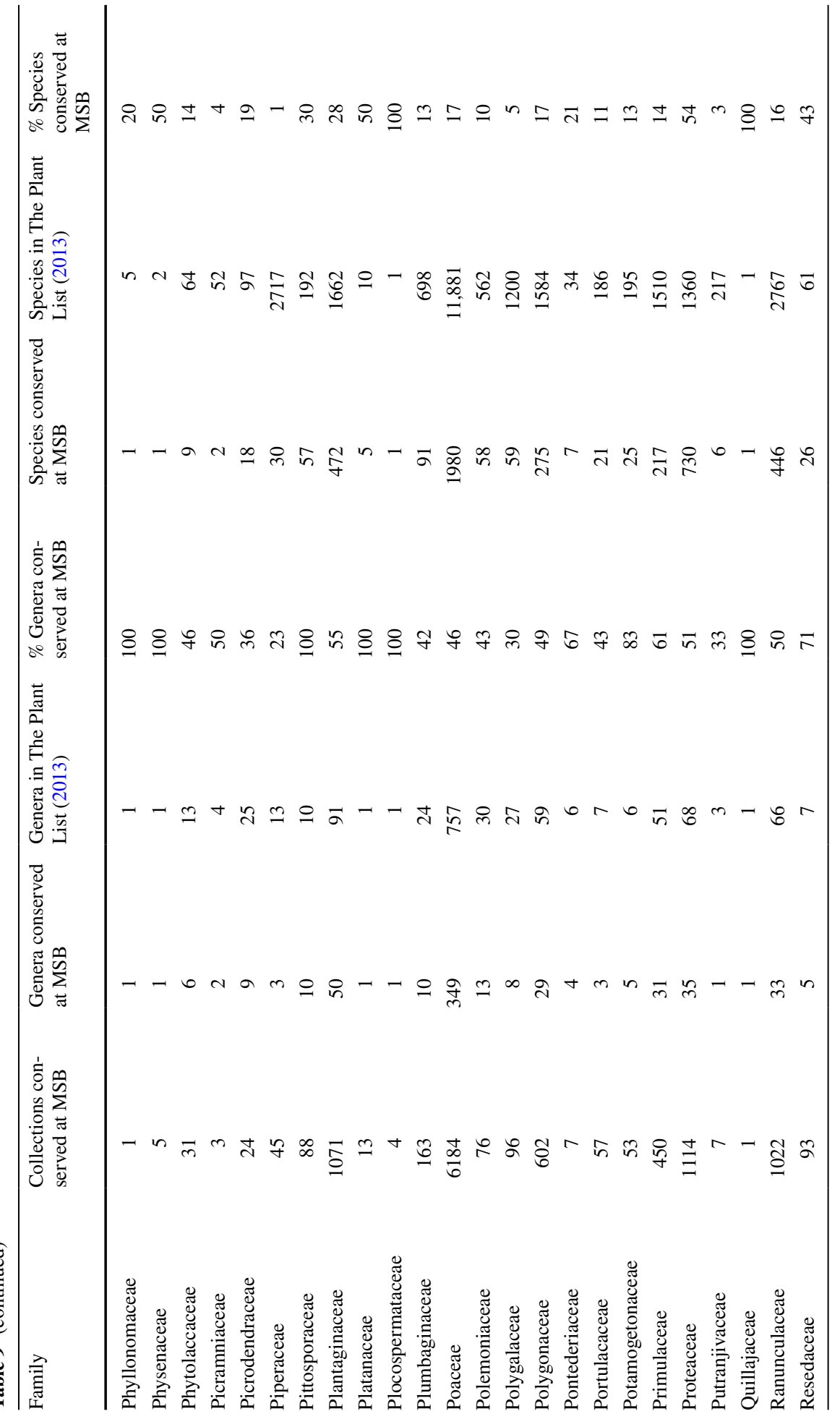




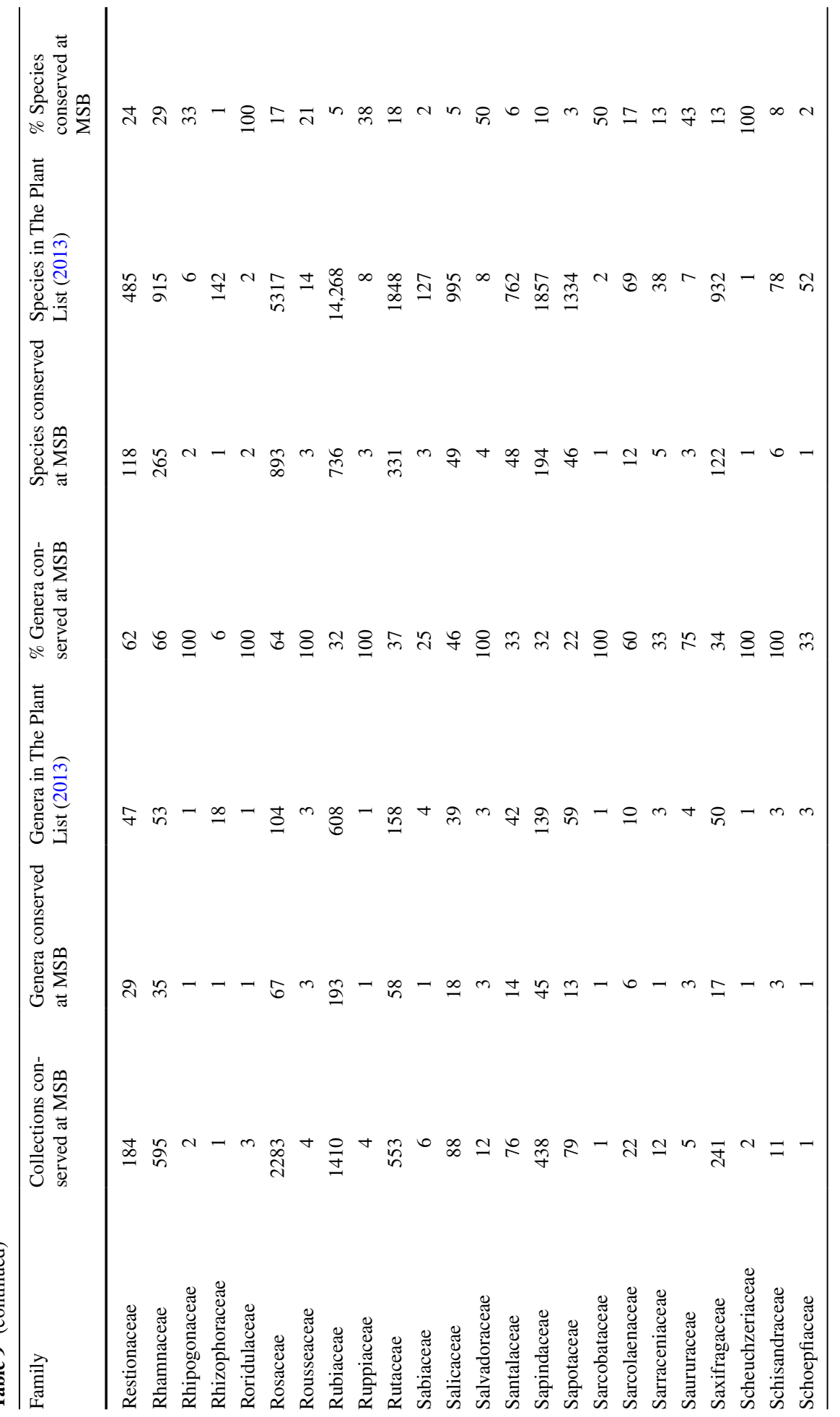




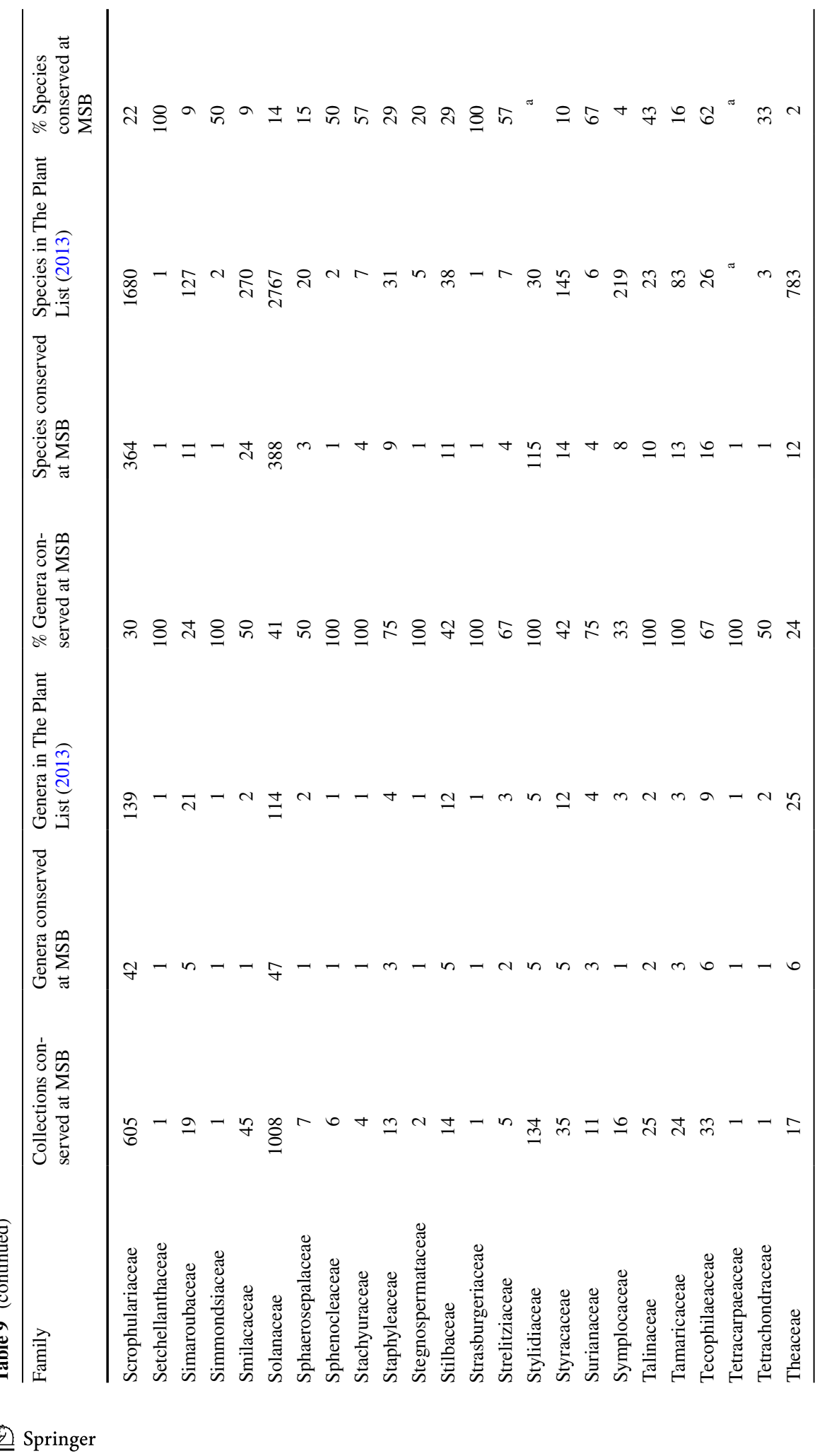




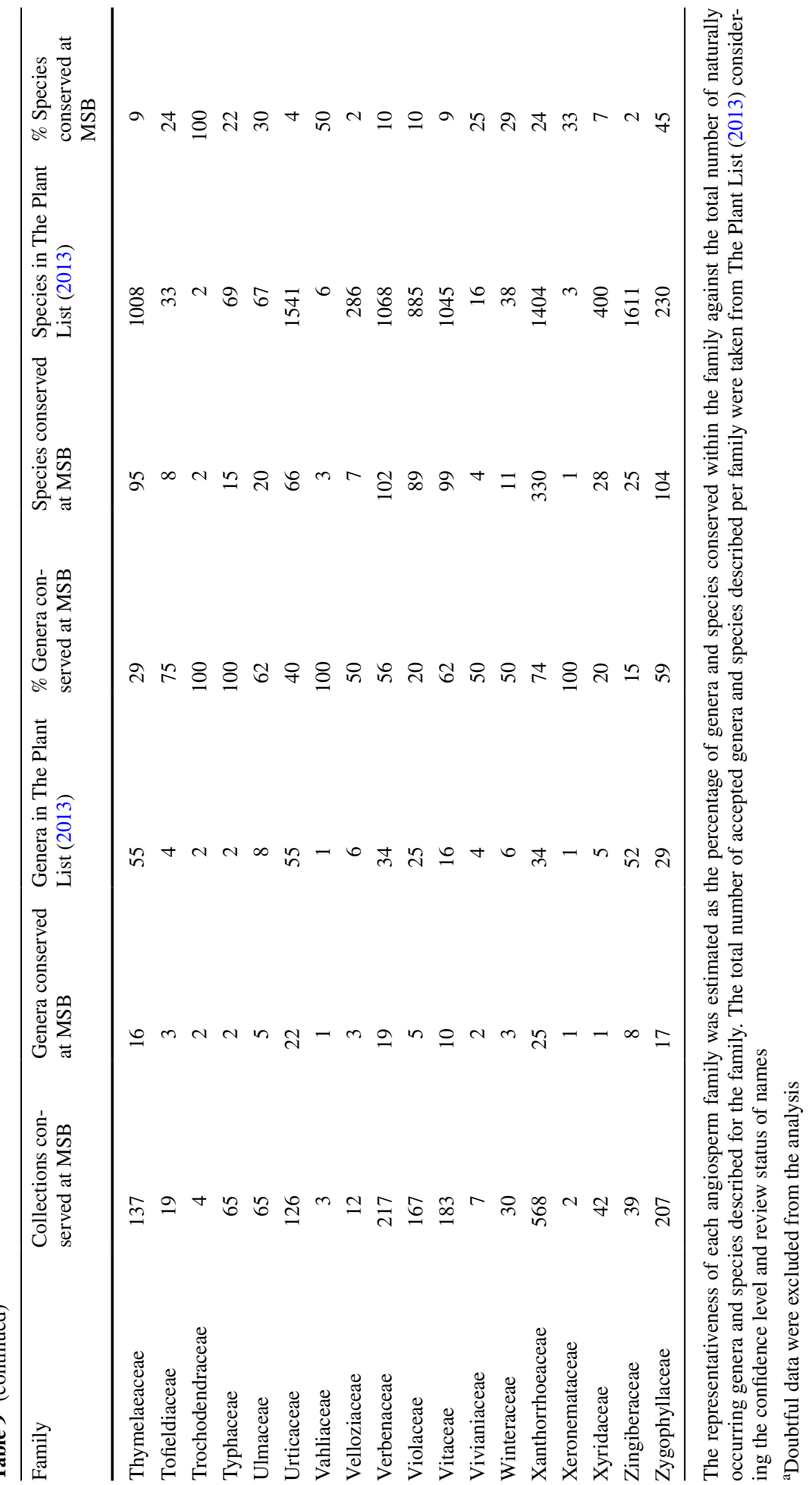




\section{Appendix 2}

See Table 10.

Table 10 Number of MSB collections originated from 35 biodiversity hotspots

\begin{tabular}{|c|c|c|}
\hline Biodiversity hotspot & Main countries & $\begin{array}{l}\text { Number of } \\
\text { MSB collections } \\
\text { originated from } \\
\text { hotspots }\end{array}$ \\
\hline
\end{tabular}

Mediterranean Basin

Portugal, Spain, France, Italy, Greece, Croatia, Mon-

13,020 tenegro, Turkey, Israel, Morocco, Tunisia, Algeria, Libya, Cyprus, Albania, Lebanon, Malta, Syria

Madagascar and the Indian Ocean Islands

Cape Floristic Region

Southwest Australia

Caucasus

Forests of East Australia

Eastern Afromontane

Mountains of Central Asia

Chilean Winter Rainfall and Valdivian Forests

Mesoamerica

Maputaland-PondolandAlbany

Succulent Karoo

Caribbean Islands

Indo-Burma

California Floristic Province

Madrean Pine-Oak Woodlands

Horn of Africa

New Zealand

Tropical Andes

Coastal Forests of Eastern Africa

Irano-Anatolian

Himalaya

Mountains of Southwest China

Cerrado
Madagascar, Reunion, Mauritius, Comoros, Seychelles, Mayotte

South Africa: South, East and Western Capes

4027

Australia: Western

Armenia, Azerbaijan, Georgia, Iran, Russia, Turkey

Australia: New South Wales, Queensland

Burundi, DRC, Eritrea, Ethiopia, Kenya, Malawi, Mozambique, Rwanda, Saudi Arabia, Somalia, Sudan, South Sudan, Tanzania, Uganda, Yemen, Zambia, Zimbabwe

Kyrgyzstan, Kazakhstan, Tajikistan, Uzbekistan, China: Xinjiang

Chile, Argentina

Mexico, Guatemala, Belize, Costa Rica, El Salvador, Honduras, Nicaragua, Panama

South Africa, Swaziland, Mozambique

South Africa, Namibia

All Caribbean Islands

Myanmar, Bangladesh, China: Yunnan, Laos, Cambodia, Vietnam, Thailand, Malaysia

Mexico: Baja California, USA: Oregon, Nevada, California

Mexico, USA: Texas, New Mexico, Arizona

1035

1011

Djibouti, Eritrea, Ethiopia, Kenya, Oman, Saudi Arabia, Somalia, Sudan, South Sudan, Tanzania, Yemen

New Zealand

Argentina, Bolivia, Chile, Colombia, Ecuador, Peru, Venezuela

Kenya, Tanzania, Mozambique, Somalia

Armenia, Azerbaijan, Georgia, Iraq, Iran, Turkmenistan

Nepal, Pakistan, Bhutan, India, China: Xizang

China: Sichuan, Xizang, Yunnan

Brazil, Bolivia, Paraguay 
Table 10 (continued)

\begin{tabular}{|c|c|c|}
\hline Biodiversity hotspot & Main countries & $\begin{array}{l}\text { Number of } \\
\text { MSB collections } \\
\text { originated from } \\
\text { hotspots }\end{array}$ \\
\hline
\end{tabular}

\section{Guinean Forests of West Africa}

Japan

Atlantic Forest

Tumbes-Choco-Magdalena

Sundaland

Wallacea

Philippines

New Caledonia

East Melanesian Islands

Western Ghats and Sri Lanka

Polynesia-Micronesia
Guinea, Sierra Leone, Cameroon, Benin, Ivory Coast, Equatorial Guinea, Ghana, Liberia, Nigeria, Sao Tome \& Principe, Togo

Japan

Brazil, Argentina, Paraguay

98

Colombia, Ecuador, Panama, Peru

Malaysia, Indonesia, Brunei, Singapore

76

Indonesia, Timor-Leste

67

62

Philippines

33

New Caledonia

26

Papua New Guinea, Vanuatu, Solomon Islands

12

India, Sri Lanka

9

Cook Islands, Fiji, French Polynesia, Guam, Kiribati, Marshall Islands, Micronesia, Nauru, Niue, Northern Mariana Islands, Palau, Pitcairn Islands, Samao,

Tokelau, Tonga, Tuvalu, Wallis and Futana

183

7
8
85
6
7
73
9
9

Total

44,130

Cultivated collections inherited the geographic origin of the wild plant population from which they were propagated or regenerated

\section{References}

Alercia A, Diulgheroff S, Mackay M (2012) FAO/bioversity multi-crop passport descriptors V.2 [MCPD V.2]. Food and Agriculture Organization of the United Nations (FAO)/Bioversity International, Rome. https://www.bioversityinternational.org/e-library/publications/detail/faobioversity-multi-crop-passport -descriptors-v2-mcpd-v2/

CBD (2012) Global Strategy for Plant Conservation: 2011-2020. Botanic Gardens Conservation International, Richmond

Cheyne P (2003) Access and benefit-sharing agreements: bridging the gap between scientific partnerships and The Conservation on Biological Diversity. In: Smith RD, Dickie JB, Linington SH, Pritchard HW, Probert RJ (eds) Seed conservation: turning science into practice. Royal Botanic Gardens, Kew, pp $3-26$

Cibrian-Jaramillo A, Hird A, Oleas N, Ma H, Meerow AW, Francisco-Ortega J, Griffith MP (2013) What is the conservation value of a plant in a botanic garden? Using indicators to improve management of ex situ collections. Bot Rev 79:559-577

Colville L, Sáez CMB, Lewis GP, Kranner I (2015) The distribution of glutathione and homoglutathione in leaf, root and seed tissue of 73 species across the three sub-families of the Leguminosae. Phytochemistry $115: 175-183$

Díaz S, Kattge J, Cornelissen JHC, Wright IJ, Lavorel S, Dray S, Reu B, Kleyer M, Wirth C, Colin Prentice I, Garnier E, Bönisch G, Westoby M, Poorter H, Reich PB, Moles AT, Dickie J, Gillison AN, Zanne AE, Chave J, Joseph Wright S, Sheremet'ev SN, Jactel H, Baraloto C, Cerabolini B, Pierce S, Shipley B, Kirkup D, Casanoves F, Joswig JS, Günther A, Falczuk V, Rüger N, Mahecha MD, Gorné LD (2016) The global spectrum of plant form and function. Nature 529(7585):167-171. https://doi. org/10.1038/nature16489. http://prodinra.inra.fr/record/342307

Dickie JB, Pritchard HW (2002) Systematic and evolutionary aspects of desiccation tolerance in seeds. In: Black M, Pritchard HW (eds) Desiccation and survival in plants drying without dying. CAB International, Wallingford, pp 239-260 
FAO (2001) International treaty on plant genetic resources for food and agriculture. Food and Agriculture Organization of the United Nations (FAO), Rome

FAO (2014) Genebank standards for plant genetic resources for food and agriculture, rev. edn. FAO, Rome

Fernández-Marín B, Míguez F, Méndez-Fernández L, Agut A, Becerril JM, García-Plazaola JI, Kranner I, Colville L (2017) Seed carotenoid and tocochromanol composition of wild Fabaceae species is shaped by phylogeny and ecological factors. Front Plant Sci 8:1428. https://doi.org/10.3389/fpls.2017.01428

Fielder H, Brotherton P, Hosking J, Hopkins JJ, Ford-Lloyd B, Maxted N (2015) Enhancing the conservation of crop wild relatives in England. PLoS ONE 10(6):e0130804. https://doi.org/10.1371/journal. pone. 0130804

Genesys. The global gateway to genetic resources. https://www.genesys-pgr.org/wiews/GBR004

Germplasm Resources Information Network (GRIN). https://www.ars-grin.gov/npgs/aboutgrin.html. Accessed Aug-Dec 2015

Godefroid S, Riviere S, Waldren S, Boretos N, Eastwood R, Vanderborght T (2011) To what extent are threatened European plant species conserved in seed banks? Biol Conserv 144:1494-1498

Griffiths KE, Balding ST, Dickie JB, Lewis GP, Pearce TR, Grenyer R (2015) Maximizing the phylogenetic diversity of seed banks. Conserv Biol 29(2):370-381

Groombridge B, Jenkins MD (2002) World Atlas of biodiversity: earth's living resources in the 21st century. UNEP-WCMC, Cambridge

Harlan and de Wet Crop Wild Relative Inventory. http://www.cwrdiversity.org/checklist/. Accessed AugDec 2015

Harlan JR, de Wet JMJ (1971) Toward a rational classification of cultivated plants. Taxon 20(4):509-517

Harrington JF (1960) Thumb rubs of drying seed. Crops Soils 13:16-17

Hay FR, Probert RJ (2013) Advances in seed conservation of wild plant species: a review of recent research. Conserv Physiol 1:1-11. https://doi.org/10.1093/conphys/cot030

Hijmans RJ, Garrett KA, Huaman Z, Zhang DP, Schreuder M, Bonierbale M (2000) Assessing the geographical representativeness of Genebank collections: the case of Biolivian wild potatoes. Conserv Biol 14(6): 1755-1765

Isaac NJ, Turvey ST, Collen B, Waterman C, Baillie JE (2007) Mammals on the EDGE: conservation priorities based on threat and phylogeny. PLoS ONE 2(3):e296. https://doi.org/10.1371/journal.pone.0000 296

IUCN (2015) The IUCN Red List of Threatened Species, Version 2015-4. http://www.iucnredlist.org. Accessed 13 Jan 2016

IUCN (2016) The IUCN Red List of Threatened Species, Version 2016-3. http://www.iucnredlist.org. Accessed 22 Dec 2016

Johnson CN (1998) Species extinction and the relationship between distribution and abundance. Nature 394:272-274

Kattge J, Diaz S, Lavorel S, Prentice IC, Leadley P, Bonisch G, Garnier E, Westoby M, Reich PB, Wright IJ, Cornelissen JHC, Violle C, Harrison SP, Van Bodegom PM, Reichstein M, Enquist BJ, Soudzilovskaia NA, Ackerly DD, Anand M, Atkin O, Bahn M, Baker TR, Baldocchi D, Bekker R, Blanco CC, Blonder B, Bond WJ, Bradstock R, Bunker DE, Casanoves F, Cavender-Bares J, Chambers JQ, Chapin FS III, Chave J, Coomes D, Cornwell WK, Craine JM, Dobrin BH, Duarte L, Durka W, Elser J, Esser G, Estiarte M, Fagan WF, Fang J, Fernandez-Mendez F, Fidelis A, Finegan B, Flores O, Ford H, Frank D, Freschet GT, Fyllas NM, Gallagher RV, Green WA, Gutierrez AG, Hickler T, Higgins SI, Hodgson JG, Jalili A, Jansen S, Joly CA, Kerkhoff AJ, Kirkup D, Kitajima K, Kleyer M, Klotz S, Knops JMH, Kramer K, Kuhn I, Kurokawa H, Laughlin D, Lee TD, Leishman M, Lens F, Lenz T, Lewis SL, Lloyd J, Llusia J, Louault F, Ma S, Mahecha MD, Manning P, Massad T, Medlyn BE, Messier J, Moles AT, Muller SC, Nadrowski K, Naeem S, Niinemets Ü, Nollert S, Nuske A, Ogaya R, Oleksyn J, Onipchenko VG, Onoda Y, Ordonez J, Overbeck G, Ozinga WA, Patino S, Paula S, Pausas JG, Penuelas J, Phillips OL, Pillar V, Poorter H, Poorter L, Poschlod P, Prinzing A, Proulx R, Rammig A, Reinsch S, Reu B, Sack L, Salgado-Negret B, Sardans J, Shiodera S, Shipley B, Siefert A, Sosinski E, Soussana JF, Swaine E, Swenson N, Thompson K, Thornton P, Waldram M, Weiher E, White M, White S, Wright SJ, Yguel B, Zaehle S, Zanne AE, Wirth C (2011) TRY - a global database of plant traits. Glob Change Biol 17:2905-2935

Kricsfalusy VV, Trevisan N (2014) Prioritizing regionally rare plant species for conservation using herbarium data. Biodivers Conserv 23:39-61

Li DZ, Pritchard HW (2009) The science and economics of ex situ plant conservation. Trends Plant Sci 14:614-621

Mace GM, Gittleman JL, Purvis A (2003) Preserving the tree of life. Science 300(5626):1707-1709. https:// doi.org/10.1126/science. 1085510 
Mattana E, Sacande M, Abdul Sanogo K, Lira R, Gomez-Barreiro P, Rogledi M, Ulian T (2017) Thermal requirements for seed germination of underutilized Lippia species. S Afr J Bot 109:223-230

Matthies D, Brauer I, Maibom W, Tscharntke T (2004) Population size and the risk of local extinction: empirical evidence from rare plants. Oikos 105:481-488

Maxted N, Kell S (2009) Establishment of a global network for the in situ conservation of crop wild relatives: status and needs. Food and Agriculture Organization of the United Nations (FAO), Rome

Maxted N, Ford-Lloyd BV, Jury SL, Kell SP, Scholten MA (2006) Towards a definition of a crop wild relative. Biodivers Conserv 15(8):2673-2685

Maxted N, Magos Brehm J, Kell S (2013) Resource book for preparation of national conservation plans for crop wild relatives and landraces. Food and Agriculture Organization of the United Nations (FAO), Rome

Mittermeier RA, Turner WR, Larsen FW, Brooks TM, Gascon C (2011) Global biodiversity conservation: The critical role of hotspots. In: Zachos FE, Habel JC (eds) Biodiversity hotspots: distribution and protection of conservation priority areas. Springer, Heidelberg. https://doi.org/10.1007/978-3-642-2099 $2-5$

Myers N, Mittermeier RA, Mittermeier CG, da Fonseca GAB, Kent J (2000) Biodiversity hotspots for conservation priorities. Nature 403:853-858

National Red List (2016) http://www.nationalredlist.org. Accessed Dec 2016

Nic Lughadha E, Govaerts R, Belyaeva I, Black N, Lindon H, Alkin R, Magil RE, Nicolson N (2016) Counting counts: revised estimates of numbers of accepted species of flowering plants, seed plants, vascular plants and land plants with a review of other recent estimates. Phytotaxa 272:82-88

Ojeda F, Arroyo J, Maranon T (1995) Biodiversity components and conservation of Mediterranean Heathlands in southern Spain. Biol Conserv 72:61-72

Ojeda F, Maranon T, Arroyo J (1996) Patterns of ecological, chorological and taxonomic diversity at both sides of the Strait of Gibraltar. J Veg Sci 7:63-72

PwC (2013) Crop wild relatives. A valuable resource for crop development. http://pwc.blogs.com/files/pwcseed-bank-analysis-for-msb-0713.pdf

RBG Kew Economy Botany Collection. Online database. http://apps.kew.org/ecbot/search. Accessed Aug 2015

RBG Kew Medicinal Plant Names Services Portal. https://www.kew.org/science/data-and-resources/tool S-and-services/medicinal-plant-names-services. Accessed Aug 2015

RBG Kew MSB Seed List. http://apps.kew.org/seedlist/

RBG Kew (1999) SEPASAL_-Survey of Economic Plants for Arid and Semi-Arid Lands—Kew Database. http://apps.kew.org/sepasalweb/sepaweb. Accessed Aug 2015

RBG Kew (2015) A global resource for plant and fungal knowledge. Science Strategy 2015-2020. Royal Botanic Gardens, Kew

RBG Kew (2016) The state of the world's plants report-2016. Royal Botanic Gardens, Kew

RBG Kew (2017) Seed Information Database (SID), Version 7.1. http://data.kew.org/sid/

Rivière S, Müller JV (2017) Contribution of seed banks across Europe towards the 2020 Global Strategy for Plant Conservation targets, assessed through the ENSCONET database. Oryx. https://doi.org/10.1017 /S0030605316001496

Rodríguez-Arévalo I, Mattana E, García L, Liu U, Lira R, Dávila P, Hudson A, Pritchard HW, Ulian T (2017) Conserving seeds of useful wild plants in Mexico: main issues and recommendations. Genet Resour Crop Evol 64:1141. https://doi.org/10.1007/s10722-016-0427-7

Seal C, Daws M, Flores J, Ortega-Baes P, Galíndez G, Leon P, Sandoval A, Ceroni Stuva A, Ramirez-Bullon N, Dávila P, Ordoñez-Salanueva CA, Yáñez-Espinosa L, Ulian T, Amosso C, Zubani L, Torres Bilbao A, Pritchard H (2017) Thermal buffering capacity of the germination phenotype across the environmental envelope of the Cactaceae. Glob Change Biol 23(12):5309-5317. https://doi.org/10.1111/ gcb. 13796

Smith PP (2007) The Millennium Seed Bank Project delivering Target 8 of the Global Strategy for Plant Conservation. Bot Gard Conserv Int 4(2). https://www.bgci.org/resources/article/0574/ Accessed Dec 2016

Smith RD, Linington SH, Wechsberg GE (1998) The millennium seed bank, the convention on biological diversity and the dry tropics. In: Prendergast HDV, Etkin NL, Harris DR, Houghton PJ (eds) Plants for food and medicine: proceedings of the joint conference of the society for economic botany and the international society for ethnopharmacology. Royal Botanic Gardens, Kew, pp 251-261

Stattersfield AJ, Crosby MJ, Long AJ, Wege DC (1998) Endemic bird areas of the world: priorities for biodiversity conservation. BirdLife International, Cambridge

Swenson JJ, Young BE, Beck S, Comer P, Córdova JH, Dyson J, Ember D, Encarnación F, Ferreira W, Franke I, Grossman D, Hernandez P, Herzog SK, Josse C, Navarro G, Pacheco V, Stein BA, Timaná 
M, Tovar A, Tovar C, Vargas J, Zambrana-Torrelio CM (2012) Plant and animal endemism in the eastern Andean slope: challenges to conservation. BMC Ecol 12:1. https://doi.org/10.1186/1472-6785 $-12-1$

Taxonomic Name Resolution Service. iPlant Collaborative, Version 4.0. http://tnrs.iplantcollaborative.org. Accessed Aug-Dec 2015

Teixido AL, Toorop PE, Liu U, Ribeiro GVT, Fuzessy LF, Guerra TJ, Silveira FAO (2017) Gaps in seed banking are compromising the GSPC's Target 8 in a megadiverse country. Biodiver Conserv 26:703716. https://doi.org/10.1007/s10531-016-1267-7

The International Plant Names Index (2015) http://www.ipni.org. Accessed Aug 2015

The Plant List (2013) Version 1.1. http://www.theplantlist.org/. Accessed Aug 2015

Tropicos.org. Missouri Botanical Garden, St. Louis. http://www.tropicos.org. Accessed Aug-Dec 2015

Ulian T, Sacandé M, Hudson A, Mattana E (2017) Conservation of indigenous plants to support community livelihoods: the MGU-useful plants project. J Environ Pann Man 60(4):668-683. https://doi. org/10.1080/09640568.2016.1166101

van Slageren MW (2003) The Millennium Seed Bank: building partnerships in arid regions for the conservation of wild species. J Arid Environ 54:195-201. https://doi.org/10.1006/jare.2001.0879

Vane-Wright RI, Humphries CJ, Williams PH (1991) What to protect? Systematics and the agony of choice. Biol Conserv 57:235-254

Vincent H, Wiersema J, Kell S, Fielder H, Dobbie S, Castaneda-Alvarez NP, Guarino L, Eastwood R, Leon B, Maxted N (2013) A prioritized crop wild relative inventory to help underpin global food security. Biol Conserv 167:265-275

Walter KS, Gillett HJ (eds) (1998) 1997 IUCN Red List of Threatened Plants. Compiled by the World Conservation Monitoring Centre. IUCN-The World Conservation Union, Gland, Switzerland and Cambridge, $862 \mathrm{pp}$

Way MJ (2003) Collecting seeds from non-domesticated plants for long-term conservation. In: Smith RD, Dickie JB, Linington SH, Pritchard HW, Probert RJ (eds) Seed Conservation: turning science into practice. Royal Botanic Gardens, Kew, pp 163-201

WCSP (2015) World checklist of selected plant families. Facilitated by the Royal Botanic Gardens, Kew. http://apps.kew.org/wcsp/. Accessed Aug 2015

Wyse SV, Dickie JB (2017) Predicting the global incidence of seed desiccation sensitivity. J Ecol 105:1082-1093 